\title{
The order Axinellida (Porifera: Demospongiae) in California
}

\author{
Thomas L. Turner ${ }^{\alpha} \&$ Sabrina Pankey ${ }^{\beta}$
}

${ }^{\alpha}$ Ecology, Evolution, and Marine Biology Department, University of California, Santa Barbara tlturner@ucsb.edu https://orcid.org/0000-0002-1380-1099

${ }^{\beta}$ Molecular Cellular and Biomedical Sciences, University of New Hampshire 46 College Rd Durham NH 03824

Sabrina.pankey@unh.edu

https://orcid.org/ 0000-0002-7061-9613

Note about species names: this pre-print is not intended to be a publication of the associated species names for the purposes of zoological nomenclature

\begin{abstract}
Sponges are common and diverse in California, but they have received little study in the region, and the identities of many common species remain unclear. Here we combine fresh collections and museum vouchers to revise the order Axinellida for California. Seven new species are described, including representatives from one family and four genera that previously had no described species in the state. One new combination is also described, and two names are placed in synonymy with existing names, resulting in a total of 13 species; a dichotomous key to differentiate them is provided. DNA data from 10 of the 13 species is combined with publicly available data to produce updated global phylogenies for the order.
\end{abstract}

\section{Introduction}

The order Axinellida is a large group of demosponges with a world-wide distribution. In its current iteration, the order is comprised of four families: the Axinellidae, Raspailiidae, Stelligeridae, and Heteroxyidae (Morrow et al. 2019; Morrow \& Cárdenas 2015), containing an estimated 669 described species across 49 genera (van Soest et al. 2021). The order was originally proposed by Lévi (1953), who hypothesized a close relationship between the families Axinellidae and Raspailiidae, but the order underwent numerous revisions and was eventually disbanded due to lack of supporting morphological evidence (Alvarez \& Hooper 2002; van Soest et al. 1990). DNA phylogenies later verified the close relationship between Axinellidae and Raspailidae, and the order was resurrected (Morrow \& Cárdenas 2015). Genetic data further led to the restoration of the family Stelligeridae (Morrow et al. 2012) and the inclusion of that family, and the Heteroxyidae, in the Axinellida. Understanding the relationships among these four families and their component genera is a work in progress, as molecular phylogenies indicate that many taxa are polyphyletic (Carballo et al. 2018; Gazave et al. 2010; Redmond et al. 2013; Thacker et al. 2013). The recent history of sponge taxonomy makes it clear that DNA data will be a major component of continued revisions, but this presents a challenge, as many sponges in museum collections have failed to yield amplifiable DNA (Vargas et al. 2012; also 
see methods below). It is therefore likely that fresh collections, which are both sequenced and morphologically described, will be crucial to continued improvement.

Six species of Axinellida were previously known from California (Lee et al. 2007a). Half were named by Max de Laubenfels in the 1930s (de Laubenfels 1932, 1935), while the others were described by Dickenson (Dickinson 1945) and Sim and Bakus (Sim \& Bakus 1986). Most were described from only one or two samples, post-preservation. Though additional samples from the Mexican Pacific have increased our understanding of some of these species (AguilarCamacho \& Carballo 2013; Gómez et al. 2002), we still know little about their status and distribution, and DNA data is absent for most. In addition to the gaps in our knowledge of described species, other morphologies have been discovered but not described (Lee et al. 2007b; a), while an unknown number also await discovery.

To fill these gaps in our knowledge, we have led an effort to collect and document the sponges of California, largely via SCUBA diving. To date, this ongoing project has netted 1155 sponge samples, mostly from diving depths but also from the intertidal zone and marinas. We previously used this collection to revise the orders Tethyida (Turner 2020) and Scopalinida (Turner 2021), and have now identified 74 of these samples as members of the Axinellida. These include fresh collections of all but one of the named shallow-water species, an additional species that was known to exist but had not been described, and four additional species that were previously unknown. By analyzing this collection together with other museum vouchered samples, we are able to present a comprehensive look at the California Axinellida, including in situ photos of live sponges, qualitative data on abundance and ranges, and quantitative spicule data. DNA sequence from 10 of the 13 species is analyzed together with publicly available genetic data to produce updated phylogenies for the order.

\section{Methods}

Collections. Sponge samples were collected by hand with a knife (Phycopsis piloerecta sp. nov. $(\mathrm{n}=2)$, Dragmacidon mexicanum $(\mathrm{n}=32)$, Endectyon (Endectyon) hyle comb. nov. $(\mathrm{n}=9)$, Endectyon (Endectyon) hispitumula sp. nov. $(\mathrm{n}=9)$, Eurypon curvoclavus sp. nov. $(\mathrm{n}=3)$, Aulospongus viridans sp. nov. $(\mathrm{n}=1)$, Cyamon neon $(\mathrm{n}=11)$, Trikentrion helium $(\mathrm{n}=2)$, Halicnemia litoria sp. nov. $(\mathrm{n}=4)$ ). Samples were placed in one-liter plastic bags with seawater, and these were kept on ice until sponges could be preserved in $95 \% \mathrm{EtOH}$. Holotypes and some other samples were vouchered with the California Academy of Sciences in San Francisco (voucher numbers with CASIZ). Additional samples were vouchered with the Santa Barbara Museum of Natural History (voucher numbers with SBMNH) and the Cheadle Center at the University of California, Santa Barbara (voucher numbers TBD). Several samples were collected during the "Los Angeles Urban Ocean Expedition 2019" bioblitz; these are archived at both the Natural History Museum of Los Angeles (voucher numbers with NHMLA) and the Florida Museum of Natural History (voucher numbers with BULA). Additional samples were acquired on loan from the California Academy of Sciences, the Natural History Museum of Los Angeles County, and the Santa Barbara Museum of Natural History. Voucher numbers are listed for each species in the systematic section, but we have also provide them in a tabular format as supplementary data deposited at Data Dryad (link TBD). This supplementary table also includes additional metadata for each sample, such as collection locations and Genbank numbers.

Seventy-nine subtidal locations were investigated while SCUBA diving: 14 around Monterey Bay and Carmel Bay, in Central California, and the rest in the Southern California 
Bight. Most sites (75\%) were searched for only a single dive, but some areas, especially in the Santa Barbara Channel, were searched repeatedly. Sites varied from 6 to $33 \mathrm{~m}$ in depth; most (75\%) were less than $22 \mathrm{~m}$ deep. Intertidal (14 sites) and harbor (23 sites) collections were less extensive, but covered a broader latitudinal range, from Drake's Estero (Marin County, Northern California) to San Diego Bay, near the Southern border of California.

Collections at each location were focused on novel sponge morphotypes and sponges that cannot be identified in the field, while also photographically documenting all field-identifiable sponges present. This allows sponge presence/absence across sites to be compiled, and these data can be used to form hypotheses about sponge distributions and habitat. Because search effort varied among sites, and a uniform protocol was not used, distribution data should be considered preliminary and non-quantitative. A supplementary table deposited at Data Dryad (link TBD) contains additional information about locations investigated, such as an estimate of search effort per location and data on sponge presence/absence for each species; a map of collection locations is also provided.

Morphology. Individual spicules were examined by digesting sponge samples in bleach. Skeletal architecture was examined by hand cutting tissue sections and digesting them with a mixture of 97\% Nuclei Lysis Solution (Promega; from the Wizard DNA isolation kit) and 3\% 20m $/ \mathrm{ml}$ Proteinase K (Promega). This digestion eliminates cellular material while leaving the spongin network intact. Spicules and sections were imaged with a D3500 SLR camera (Nikon) with a NDPL-1 microscope adaptor (Amscope) attached to a compound triocular microscope. Measurements were made on images using ImageJ (Schneider et al. 2012), after calculating the number of pixels per mm with a calibration slide. Unless otherwise specified, spicule length was measured as the longest possible straight line from tip to tip, even when spicules were curved or bent. Spicule width was measured at the widest point, excluding adornments like swollen tyles. All spicule measurements are available as raw data at Data Dryad (link TBD).

Genotyping. DNA was extracted with several different kits: the Wizard Genomic DNA Purification kit (Promega), the Qiagen Blood \& Tissue kit, and the Qiagen Powersoil kit. Though we have found that the Wizard kit works well on sponges from other sponge orders, PCR amplifications from these extractions usually failed from the sponges included here, even when extractions were diluted. Qiagen kits, which include a column filtration, were more successful, though extracts from the Blood \& Tissue kit often required dilution. These differences are presumably due to co-purification of PCR inhibiting compounds in these species.

Two primer sets were used to sequence a fragment of the coxl mitochondrial locus. Most samples were genotyped at a $\sim 1200 \mathrm{bp}$ fragment using the following primers (LCO1490: 5-GGT CAA CAA ATC ATA AAG AYA TYG G-3'; COX1-R1: 5'-TGT TGR GGG AAA AAR GTT AAA TT-3'); these amplify the "Folmer" barcoding region and the "co1-ext" region used by some sponge barcoding projects (Rot et al. 2006). The "Folmer" region alone was amplified from some samples using the following primers: (LCO1490: 5'-GGT CAA CAA ATC ATA AAG AYA TYG G-3'; HCO2198: 5'-TAA ACT TCA GGG TGA CCA AAR AAY CA-3') (Folmer et al. 1994). Though both primer sets worked well for the Raspailliidae, neither worked in the Stelligeridae, and only one of two species of Axinellidae was successful. In fresh samples, the Folmer primers often produced an amplicon, but sequencing revealed it to be a mixed sample, presumably contaminated by the unicellular (or multicellular) symbionts abundant in sponges. 
Three primer sets were used to amplify portions of the 28S rDNA nuclear locus. Most species were sequenced across the D1-D5 region by combining two amplicons: the $~ 800$ bp D1D2 region using primers Por28S-15F (5'-GCG AGA TCA CCY GCT GAA T-3') and Por28S878R (5'-CAC TCC TTG GTC CGT GTT TC-3') and the $~ 800$ bp D3-D5 region using primers Por28S-830F (5'-CAT CCG ACC CGT CTT GAA-3') and Por28S-1520R (5'-GCT AGT TGA TTC GGC AGG TG-3') (Morrow et al. 2012). The D1-D2 primers failed to yield products for both Endectyon species. For these samples, the C2-D2 region (covering 50\% of the D1-D2 region) was amplified with C2 (5'-GAA AAG AAC TTT GRA RAG AGA GT-3') and D2 (5'TCC GTG TTT CAA GAC GGG-3') (Chombard et al. 1998).

PCR was performed using a Biorad thermocycler (T100); the following conditions were used for the cox 1 locus: $95^{\circ} \mathrm{C}$ for $3 \mathrm{~min}$, followed by 35 cycles of $94^{\circ} \mathrm{C}$ for $30 \mathrm{sec}, 52^{\circ} \mathrm{C}$ for 30 sec, $72{ }^{\circ} \mathrm{C}$ for 90 seconds, followed by $72^{\circ} \mathrm{C}$ for 5 minutes. The 28S C2-D 2 region was amplified with the same conditions, except a $57^{\circ} \mathrm{C}$ annealing temperature and 60 second extension time; the 28S D1-D2 and D3-D5 regions used a $53^{\circ} \mathrm{C}$ annealing temperature and 60 second extension time. PCR was performed in $50 \mu \mathrm{l}$ reactions using the following recipe: $24 \mu \mathrm{l}$ nuclease-free water, $10 \mu \mathrm{l} 5 \mathrm{x}$ PCR buffer (Gotaq flexi, Promega), $8 \mu \mathrm{l} \mathrm{MgCl}, 1 \mu \mathrm{l} 10 \mathrm{mM}$ dNTPs (Promega), $2.5 \mu \mathrm{l}$ of each primer at $10 \mu \mathrm{M}, 0.75$ bovine serum albumin $(10 \mathrm{mg} / \mathrm{ml}$, final conc $0.15 \mathrm{mg} / \mathrm{ml})$, $0.25 \mu \mathrm{l}$ Taq (Gotaq flexi, Promega), $1 \mu \mathrm{l}$ template. ExoSAP-IT (Applied Biosystems) was used to clean PCRs, which were then sequenced by Functional Biosciences using Big Dye V3.1 on ABI 3730xl instruments. Blastn was used to verify that the resulting traces were of sponge origin. All sequences have been deposited in GenBank; accession numbers are shown in the phylogenies and also listed in the supplementary table in Data Dryad (link TBD).

PCR was attempted from a variety of older museum vouchers and was nearly always unsuccessful. These include samples of multiple Halicnemia species from the California Academy of Sciences, Raspailia hymani from the Santa Barbara Museum of Natural History, and the holotypes of Trikentrion helium, Cyamon argon, Dragmacidon oxeon, and Stylissa letra from the Natural History Museum of Los Angeles. Most DNA extractions produced little detectable DNA, and PCR amplification of these samples failed to yield any bands at either locus. When PCR on these samples yielded a product, it was usually due to contamination, and this contamination appeared to be from past handling of the vouchers rather than contamination during molecular work. For example, the $C$. argon holotype produced a $28 \mathrm{~S}$ sequence from a Tetractinellid: the molecular lab performing PCR had not previously amplified sponge DNA from this order. Extractions performed on multiple Halicnemia from the California Academy of Sciences all produced a $28 \mathrm{~S}$ sequence matching a common California Suberites. This could have result from contamination of the samples during molecular work, but these samples were not extracted as a set, and all were contaminated with the same sequence, so contamination of the vouchers by a past taxonomist seems most likely. The only museum sample that yielded DNA sequence that was likely native was a sample of Halicnemia weltoni sp. nov.. This sequence is both unique and has a phylogenetic position supported by its morphology.

Phylogenetic methods. Axinellid sequences were collected from GenBank using a combination of blast and the NCBI taxonomy browser; effort was made to find every available sequence at these loci from sponges in the Axinellida (at 28S) or the Raspailiidae (at cox1), as well as relevant outgroups. For cox1, sequences were included if they minimally encompassed the Folmer barcoding region. For $28 \mathrm{~S}$, sequences were included if they minimally encompassed the C2-D2 barcoding region. Combined, the previously published sequences included in the 
phylogenies are from 19 different publications and several unpublished datasets (Belinky et al. 2012; Erpenbeck et al. 2007a; b, 2012, 2016; Gazave et al. 2010; Holmes \& Blanch 2007; Huchon et al. 2015; Idan et al. 2018; Kayal \& Lavrov 2008; Lavrov et al. 2008; Lim et al. 2017; Morrow et al. 2012, 2013, 2019; Nichols 2005; Richelle-Maurer et al. 2006; Schuster et al. 2021; Turon et al. 2018). Hymeraphia vaceleti 28S sequence was provided by Christine Morrow.

Sequence alignments were produced using MAFFT v.7 online (Katoh et al. 2017). Phylogenies were estimated with maximum likelihood using a GTR model in IQ-Tree (Nguyen et al. 2015; Trifinopoulos et al. 2016); the ultrafast bootstrap was used to measure node confidence (Hoang et al. 2018). Figures were produced by exporting IQ-Tree files to the Interactive Tree of Life webserver (Letunic \& Bork 2019).

\section{Results}

\section{Phylogenies}

A phylogeny for the $28 \mathrm{~S}$ ribosomal RNA locus is shown in figure 1 . We successfully sequenced portions of this locus from 21 California samples, representing 10 of the 13 species of California Axinellida. A minimum of $1224 \mathrm{bp}$ was sequenced from at least one sample from each species. We compare these new sequences to 91 publicly available sequences; these samples vary greatly in length (mean $=1626 \mathrm{bp}$ ), but were only included if they encompassed the highly variable C2D2 region ( 500 bp) targeted by the Sponge Barcoding Project (Chombard et al. 1998). Our primary aim was to use these phylogenies as part of an integrative revision of California species, so we chose breadth (including as many species as possible) over depth (including only the species with the most data, to better resolve branching order). Though deeper branches in the phylogeny are poorly resolved, we were able to generate strong phylogenetic hypotheses for many important clades and confidently identify phylogenetic species. Note that the family Heteroxyidae is absent because no species in this family have data available at the 28S C2-D2 region.

The family Axinellidae contains 12 genera; our phylogeny includes species from seven of these, including the type species from five. Consistent with previous results, we find the family to be highly polyphyletic (Carballo et al. 2018; Gazave et al. 2010; Morrow et al. 2012; Redmond et al. 2013; Thacker et al. 2013). The type species of Ptilocaulis and Reniochalina fall within a clade, shown in green, that is mostly comprised of the Raspailiidae. The type species from Phakellia and Cymbastela, along with a subset of Axinella species, fall into several other well supported clades (shown in black) that include type species from other orders like the Agelasida and Bubarida. Both California species, however, fall within a clade, shown in orange, that includes the type species Axinella polypoides (Schmidt 1862). The presence of the California species in this "Axinellidae sensu stricto" clade indicates that they will likely remain in this family after future revisions reconcile the phylogeny and taxonomy. Sequences from Dragmacidon mexicanum form a clade with the only other Dragmacidon with data at this locus. In a separate phylogeny of the D3-D5 region of 28S (not shown), all 5 species of Dragmacidon with available data fell into an exclusive clade, so this genus may prove to be less polyphyletic than Axinella. Phycopsis piloerecta sp. nov. is the first of its genus with data at this locus.

The family Stelligeridae (fig. 1, in blue) was recently revised by Morrow et al. (2019) using a combination of DNA and morphological data. As such, it now forms a monophyletic group with the exception of Plenaster craigi. Of the three new species of California stelligerids described below, we were able to obtain 28S sequence from two. Morphologically, both species 
are in the genus Halicnemia, which is polyphyletic based on this single locus. As data is only available from a few species thus far, not including the type species H. patera (Bowerbank 1864), revising this genus awaits further data.

Sequences are unexpectedly variable for Halicnemia litoria sp. nov., with pairwise differentiation of $4.6 \%$ between two isolates collected within a few kilometers of each other. The $28 \mathrm{~S}$ locus is multicopy, and though gene conversion homogenizes these copies, there can sometimes be intragenomic polymorphism within species (Simon \& Weiss 2008). This may be responsible for the apparently high variability among samples of this species, as one of the three individuals sequenced had a large number of bases that appeared to be variable in the raw sanger sequence data, and many of these variable sites were the same as the sites that differentiated the other two individuals.

The family Raspailiidae is large, with 5 subfamilies and 26 genera. New and published $28 \mathrm{~S}$ sequences from the family largely fall within a single well-supported clade (shown in green), containing representatives of 13 of these genera. This paraphyletic clade also includes a few species currently placed in other families within the Axinellida (Ptilocaulis, Reniochalina), or in other orders (Tethyspira (Bubarida: Dictyonellidae); Epipolasis (Suberitida:

Halichondriidae), Ceratoporella (Agelisida: Astroscleridae). Data from the mitochondrial cox1 locus tell a similar story, though the relationships among some Raspailliidae sub-clades are different; these data are shown in figure 2, with several Axinellidae sensu stricto, including new sequence from D. mexicanum, as outgroups. All six of the sequenced Raspailiidae from California fall within this large raspailiid clade at both loci, supporting their inclusion in the family.

In addition to the paraphyletic inclusions mentioned above, many raspailiid subfamilies, genera, and subgenera are polyphyletic. This is consistent with previous analyses (Erpenbeck et al. 2007b; Thacker et al. 2013), but our expanded dataset adds weight to this conclusion and offers additional insights. For example, the raspailiid subfamily Cyamoninae was previously represented only by Trikentrion flabelliforme. Surprisingly, this species clustered with members of the Thrinacophorinae at both 28S (Erpenbeck et al. 2007b) and 18S (Redmond et al. 2013). We have added two California Cyamoninae, Cyamon neon and Trikentrion helium: like $T$. flabelliforme, these species have polyactine megascleres not found in other subfamilies, and rare outside the order Tetractinellida (van Soest et al. 2012). Though the three species fall into the same clade, clustered with Thrinacophorinae and Raspailiinae, they do not form an exclusive clade with each other. This result is highly supported at both the $28 \mathrm{~S}$ and cox 1 loci and therefore appears to be a legitimate reflection of the species tree. It would be surprising if polyactine megascleres had evolved multiple times in the Raspailiidae; the alternative explanation of multiple losses may be more likely.

It is also notable that the newly generated cox 1 sequence from Trikentrion helium (from California), is identical to sequences of both Thrinacophora rhaphidophera (from Vietnam) and Thrinacophora cervicornis (from Australia) across the entire Folmer barcoding region ( 650 bp; $1150 \mathrm{bp}$ of cox 1 were sequenced for $T$. helium, but only the Folmer region is available from the other species). This cannot be due to contamination, as no Raspailiidae, other than those sequenced in the current paper, have ever been present in the lab where the current work was done. As the morphology of these species is quite distinct, and the sequences at the $28 \mathrm{~S}$ locus well differentiated, this adds to a list of examples of a slow rate of evolution at the cox 1 locus in sponges (Huang et al. 2008; López-Legentil et al. 2010; Pöppe et al. 2010). 
Five species of Eurypon are represented in the $28 \mathrm{~S}$ tree, including E. curvoclavus sp. nov. All five species are separated from each other in the phylogeny, emphasizing that the genus, as currently defined, is not tenable. As there are over 50 species in the genus, acquiring genetic data from more species - especially the type species, E. clavatum - would be helpful in forming new hypotheses regarding the evolution of encrusting raspailiids.

The newly sequenced Aulospongus viridans sp. nov. does not form a clade with other Aulospongus at $28 \mathrm{~S}$, but with only a few members sequenced, and no data from the type species, firm conclusions regarding this genus seem premature. Interestingly, at cox1, A. viridans is closely related to the monotypic Pandaros acanthifolium. This species is currently placed in the Microcionidae (order Poecilosclerida), but, as noted in the Systema Porifera, "Pandaros is a borderline taxon that could be legitimately included in either Raspailiidae or Microcionidae" (Hooper 2002b). Though A. viridans shares lightly spined, slightly rhabdostyle-shaped styles with $P$. acanthifolium, the new species does not fit the other important features of the genus Pandaros as defined by Hooper (2002). It seems possible that $A$. viridans will be included in a revised version of the genus Pandaros in the future, once more species have been sequenced and the defining features of this clade have been determined. In the meantime, we suggest that Pandaros be moved to the family Raspailiidae.

Two newly sequenced Endectyon are the only members from the California Axinellida that appear closely related to one another. The genetic data provide strong evidence that they are indeed sister species, and not morphotypes of the same species, because there are fixed genetic differences at both $28 \mathrm{~S}$ and cox1. Because nuclear and mitochondrial genes are unlinked, even low amounts of gene flow between them should disrupt such a pattern; because these species are sympatric, this indicates that other types of reproductive isolation separate them.

These California Endectyon also provide an interesting perspective on the phylogenetic signal of acanthostyle spine morphology. The two California Endectyon form a clade with Endectyon (Endectyon) delaubenfelsi at 28S, and both E. (E.) delaubenfelsi and E. (E.) fruticosum at cox1. Also included in this clade is Raspailia (Raspailia) phakellopsis: the description of this species shows large, recurved hooks on the acanthostyles (Hooper 1991). This is a trait shared by Endectyon but absent from the other named species in the phylogeny. The only exception is Ectyoplasia, which have similar recurved spines, and at 28S, this clade is sister to the Endectyon clade. These results may indicate that the type of spination on acanthostyles is more phylogenetically informative than previously realized. In contrast, the loss of acanthostyles has most likely happened repeatedly. Species without acanthostyles often grouped with other species without acanthostyles, but these groups are dispersed throughout the phylogeny (e.g. [Sollasella + Ceratopsion $],[$ Axechina + Reniochalina $])$. 
bioRxiv preprint doi: https://doi.org/10.1101/2022.03.02.482672; this version posted March 4, 2022. The copyright holder for this preprint (which was not certified by peer review) is the author/funder, who has granted bioRxiv a license to display the preprint in perpetuity. It is made available under aCC-BY-NC-ND 4.0 International license.

Figure 1. ML phylogeny of the large ribosomal subunit (28S). Genbank accession numbers are shown; bold indicates new sequences; asterisks designate type species. Node confidence is based on bootstrapping. Scale bar indicates substitutions per site. Root placement based on Redmond et al. (2013). Orange = "Axinellidae sensu stricto", Blue = Stelligeridae, Green = paraphyletic clade of mainly Raspailiidae.

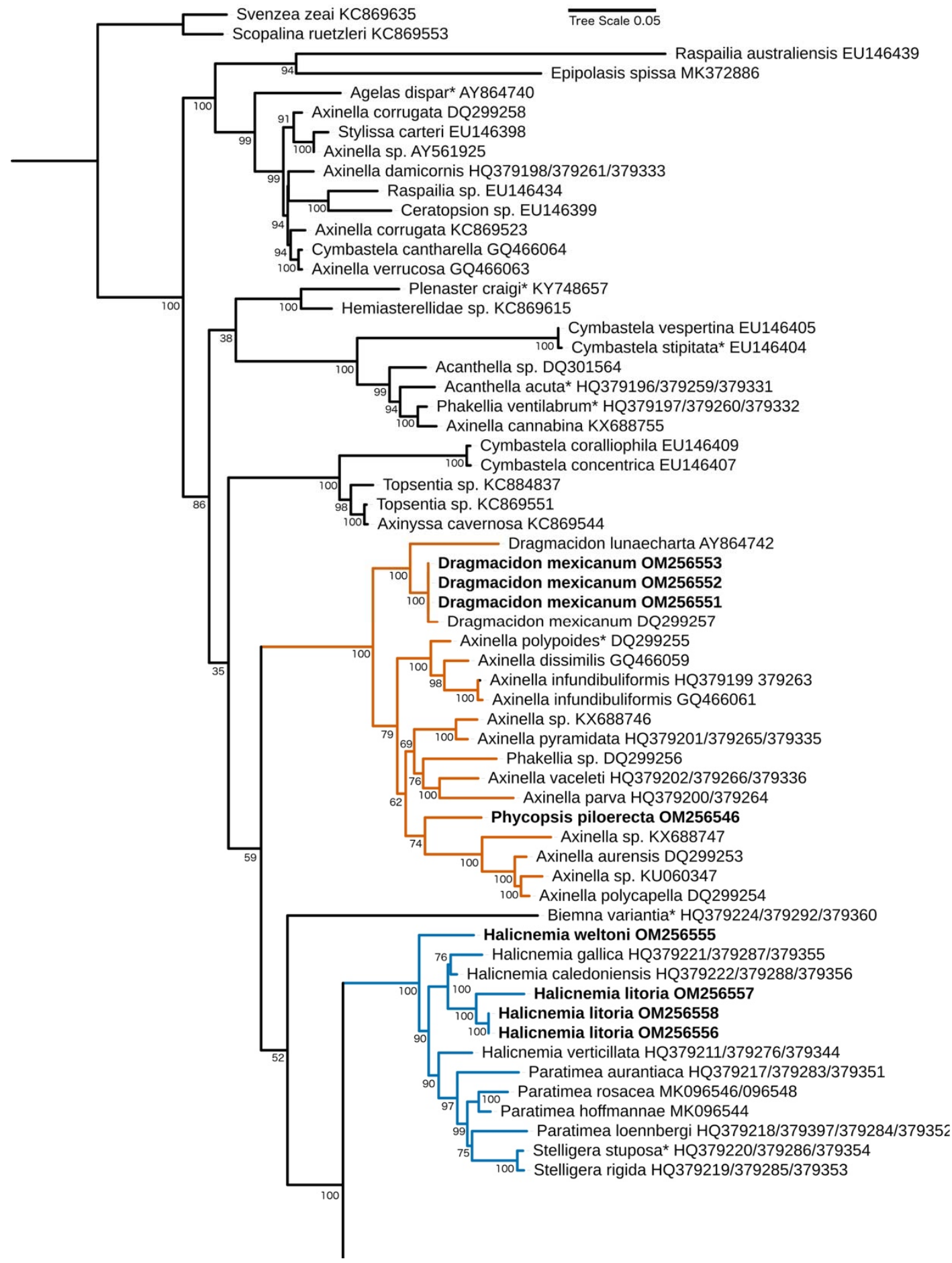


bioRxiv preprint doi: https://doi.org/10.1101/2022.03.02.482672; this version posted March 4, 2022. The copyright holder for this preprint (which was not certified by peer review) is the author/funder, who has granted bioRxiv a license to display the preprint in perpetuity. It is made available under aCC-BY-NC-ND 4.0 International license.

Figure 1. Cont.

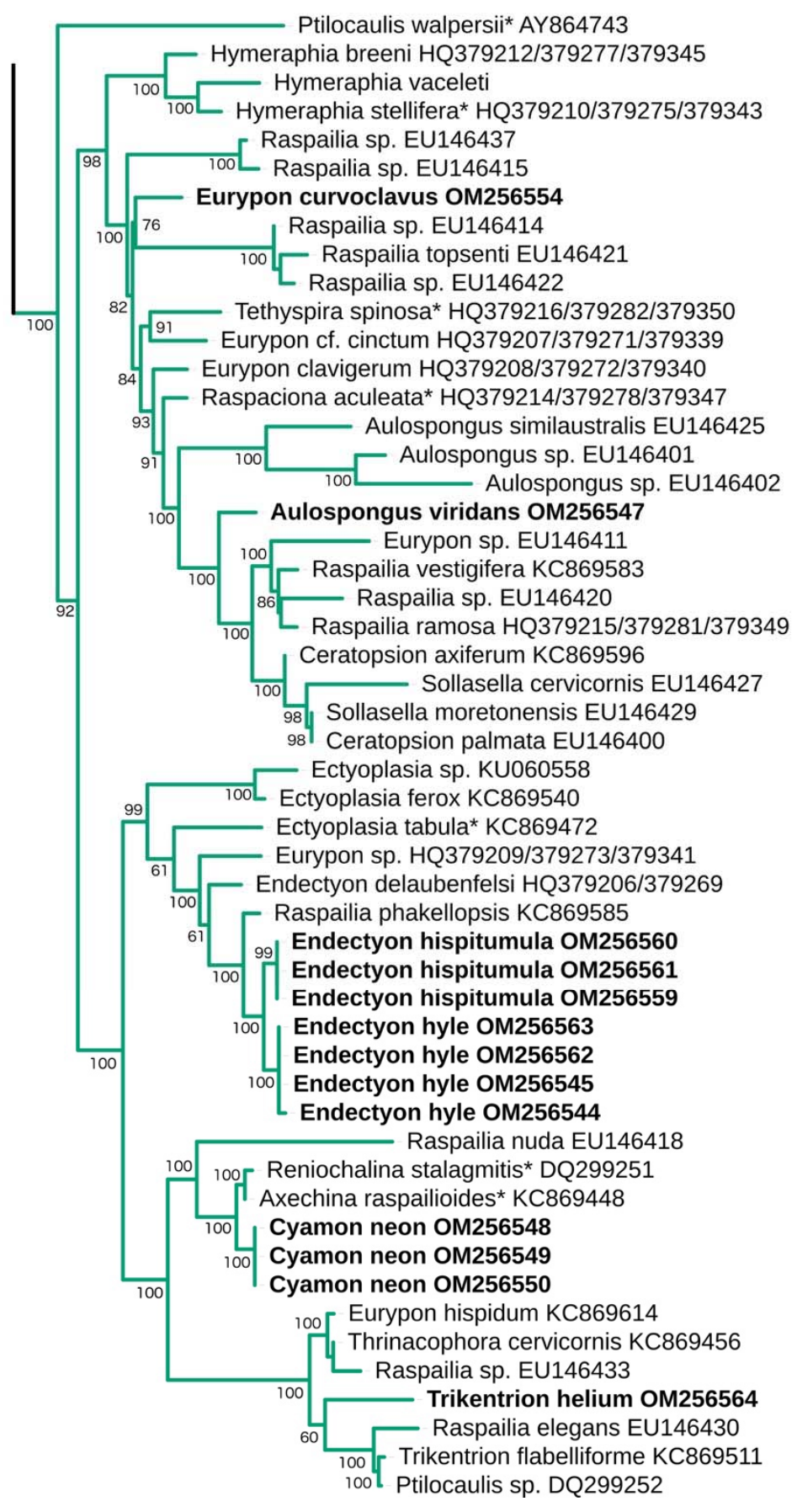


bioRxiv preprint doi: https://doi.org/10.1101/2022.03.02 482672; this version posted March 4, 2022. The copyright holder for this preprint (which was not certified by peer review) is the author/funder, who has granted bioRxiv a license to display the preprint in perpetuity. It is made available under aCC-BY-NC-ND 4.0 International license.

Figure 2. ML phylogeny of the cox1 mitochondrial locus. Genbank accession numbers are shown; bold indicates new sequences; asterisks designate type species. Node confidence is based on bootstrapping. Scale bar indicates substitutions per site. Root placement based on Redmond et al. (2013). Green = paraphyletic clade of mainly Raspailiidae; Orange = subset of "Axinellidae sensu stricto" sequences used as outgroups.

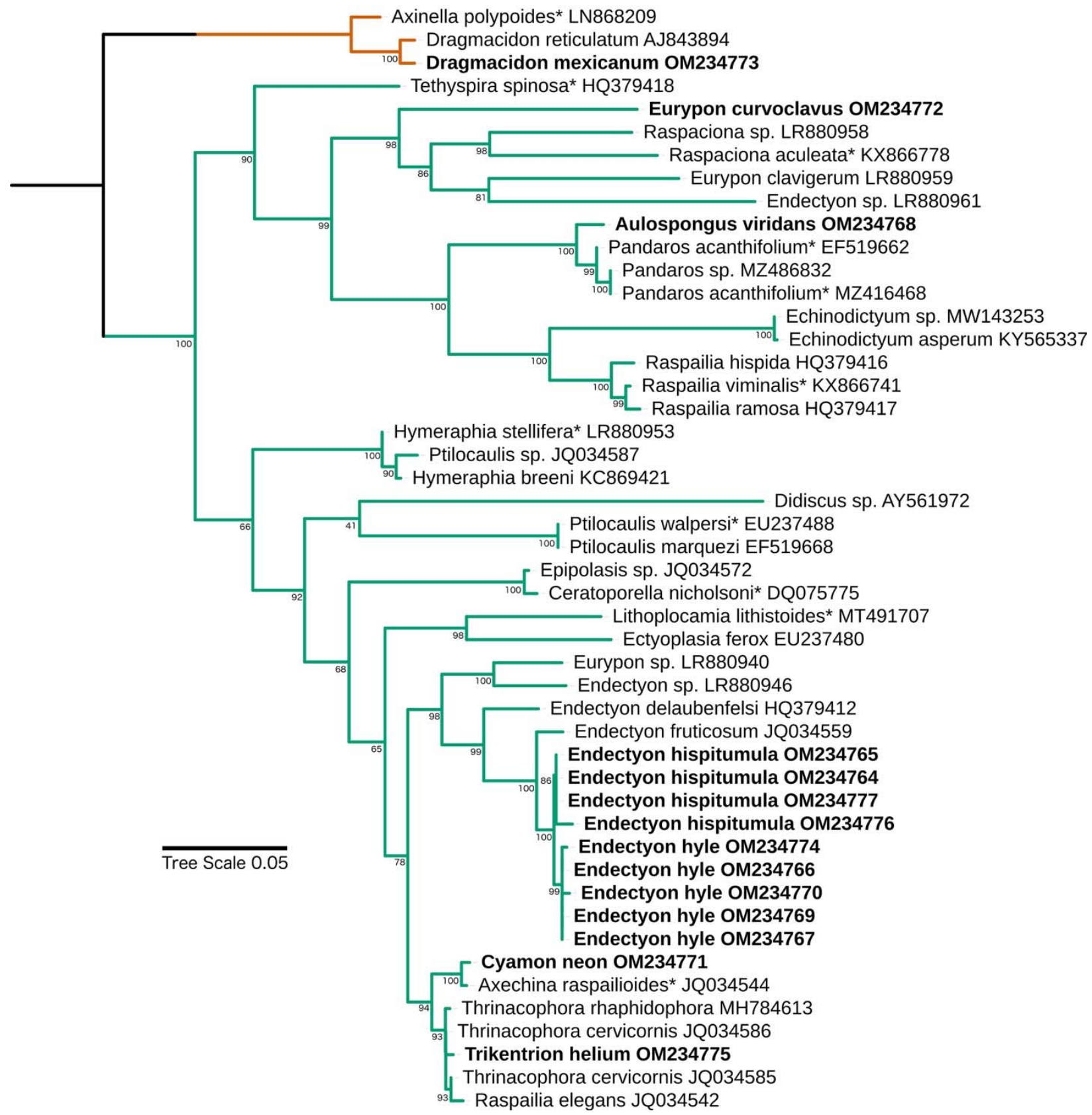




\section{$\underline{\text { Systematics }}$}

\section{Summary of California Axinellida}

Family Axinellidae (Carter 1875)

Phycopsis piloerecta sp. nov.

Dragmacidon mexicanum (de Laubenfels 1935)

Family Raspailiidae (Nardo 1833)

Subfamily Raspailiinae (Nardo 1833)

Endectyon (Endectyon) hyle comb. nov. (de Laubenfels 1930)

Endectyon (Endectyon) hispitumula sp. nov.

Raspailia (Raspaxilla) hymani (Dickenson 1945)

Eurypon curvoclavus sp. nov.

Aulospongus viridans sp. nov.

Subfamily Cyamoninae (Hooper 2002)

Cyamon neon (de Laubenfels 1930)

(Cyamon argon (Dickenson 1945) placed in synonymy with C. neon)

Cyamon koltuni (Sim \& Bakus 1986)

Trikentrion helium (Dickenson 1945)

(Trikentrion catalina (Sim \& Bakus 1986) placed in synonymy with T. helium)

Family Stelligeridae (Lendenfeld 1898)

Halicnemia litoria sp. nov.

Halicnemia monteriensis sp. nov.

Halicnemia weltoni sp. nov. 


\section{Family Axinellidae (Carter 1875)}

\section{Genus Phycopsis (Carter 1883)}

Phycopsis piloerecta sp. nov.

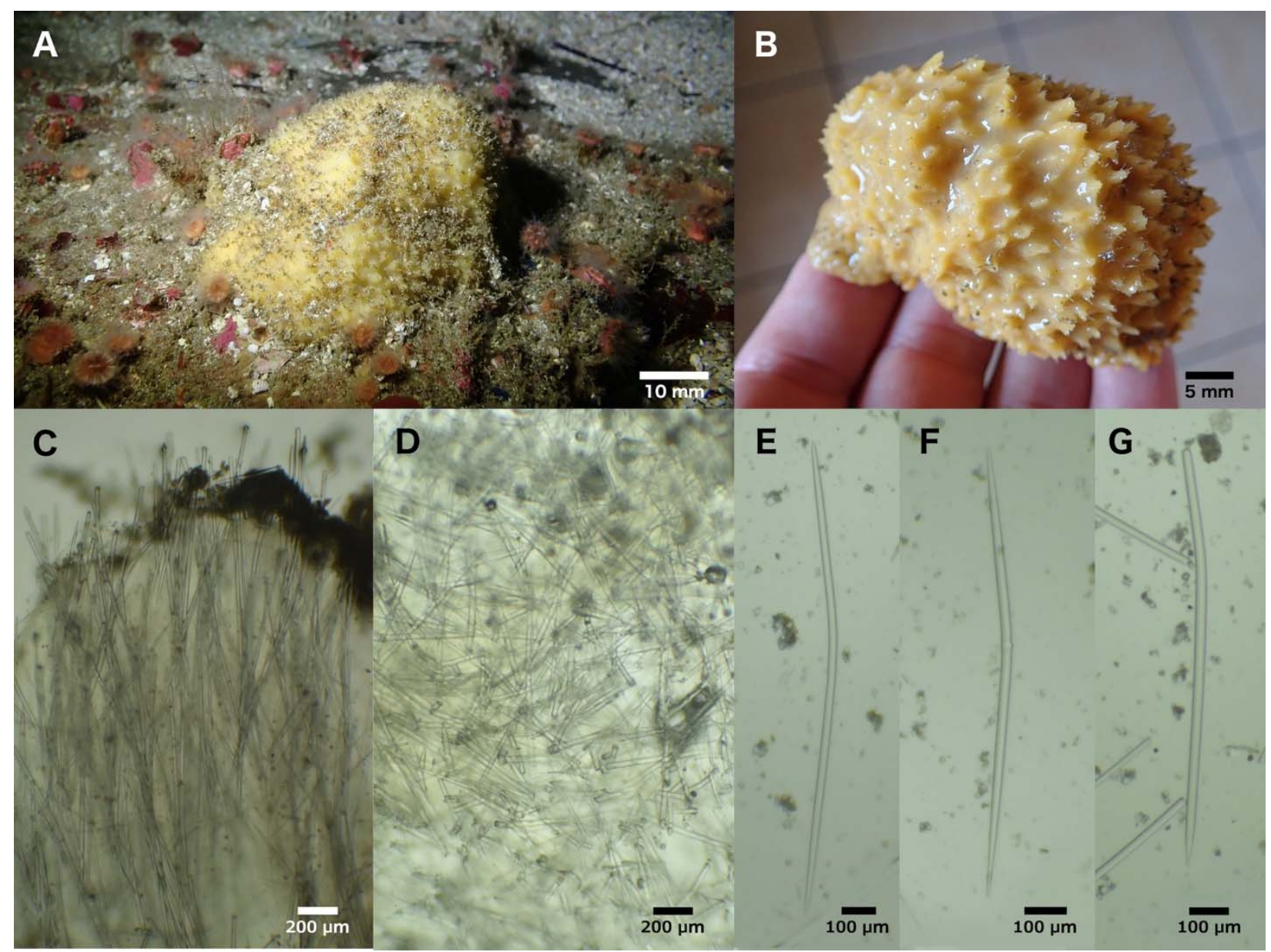

Figure 3. Phycopsis piloerecta. A: Field photo of holotype (TLT1107, TBD). B: Photo of paratype (TLT1132, TBD) before preservation. C-G: Skeleton and spicules from holotype. C: Skeleton at periphery, with surface debris. D: Disorganized internal skeleton. E: Oxea. F: Centrylote oxea. G: Style.

Material examined. Holotype: TLT 1007 (CASIZ TBD), Yellowbanks, Santa Cruz Island (33.99432, -119.51910), 24-30 m, 9/15/21, collected by TT. Additional sample: TLT 1132 (CCBER TBD), same date and location, collected by Christoph Pierre.

Etymology. From the word piloerection, the process that causes skin to form "goosebumps" and hair to stand up, creating a pattern similar to the surface of this sponge.

Morphology. Samples are both cushion-shaped, irregular mounds, pale yellow when alive and beige in ethanol. Surface covered in raised projections, 1-3 mm apart, 1-3 $\mathrm{mm}$ in height, with 
spicules projecting an additional $0.5 \mathrm{~mm}$. When alive, holotype was approximately $60 \times 35 \mathrm{~mm}$ across, $24 \mathrm{~mm}$ in maximum thickness; sampled portion approximately 35 x 35 x $24 \mathrm{~mm}$.

Skeleton. A dense and chaotic mass of spicules internally, with no apparent organization. Spicules become roughly parallel towards the periphery, pointing outwards, and form vague plumose tracts. Some of these tracts end in tufts of spicules that pierce the surface of the sponge.

Spicules. Styles and oxeas, with some intermediates; one strongyle also present.

Oxeas: curved or bent, usually near center; sometimes with weak centrylote swelling. Dimensions highly variable, but without clear size categories; 533-957-1476 x 5-24-33 $\mu \mathrm{m}$ $(n=78)$.

Styles: Less common than oxeas (18\% of spicules), with similar dimensions. 606-1178-2166 x 517-27 $\mu \mathrm{m}(\mathrm{n}=17)$.

Distribution and habitat. Found at only a single location: a rocky reef near Yellow Banks, Santa Cruz Island. The site is a rocky outcrop, typical of other rocky reefs in the region, but most other sites searched in the Northern Channel Islands have been in less than $20 \mathrm{~m}$ of water, while this site was 24-30 $\mathrm{m}$ in depth. The deep-water kelp Pelagophycus porra is known to have occurred at the site in the recent past, but no kelp was seen when the samples were collected. The species appeared to be common at the site at the time of collection.

Discussion. Spicules, skeletal organization, and 28S sequences are all consistent with placement in the Axinellidae. This sample is a poor fit to the genus Axinella, whose members are generally branching, arborescent, or bushy, but not encrusting or mound-shaped. Axinella may have spicules that project slightly, but are usually smooth, in contrast with the tufted projections that cover this sponge. Sponges in the genus Phycopsis have a similar skeletal structure as Axinella, but are characterized by having surface projections (Alvarez \& Hooper 2002). These sponges are also usually upright and branching, but P. styloxeata (Lage et al. 2013), from Brazil, is cushionshaped. Though surface projections are a dubious taxonomic character, we place the current sponge in this genus, as it fits poorly in any other genus in the family. No 28S data is yet available from other Phycopsis species, but we would not be surprised to find that the genus is polyphyletic, in which case a new genus would likely be needed to hold $P$. piloerecta.

Six species of Phycopsis are known from the tropical South Pacific, with single species known from the North Atlantic and South Atlantic. The South Atlantic species P. styloxeata, mentioned above, is the most similar to the new species, but has multiple size categories of styles, and all spicules are much smaller than the new species described here (see table 1 in Lage et al. 2013).

This species can be tentatively identified in the field based on morphology alone, but there is a similar looking species in the order Bubarida that will be described in a later work. Both species are macroscopically hispid, but the undescribed species appears more uniformly hairy and $P$. piloerecta has a more fleshy-looking ectosome. The undescribed species is variable in color, but has not yet been found in yellow, which may also prove to be a good field character. 
Genus Dragmacidon (Hallman, 1917)

\section{Dragmacidon mexicanum (de Laubenfels 1935)}

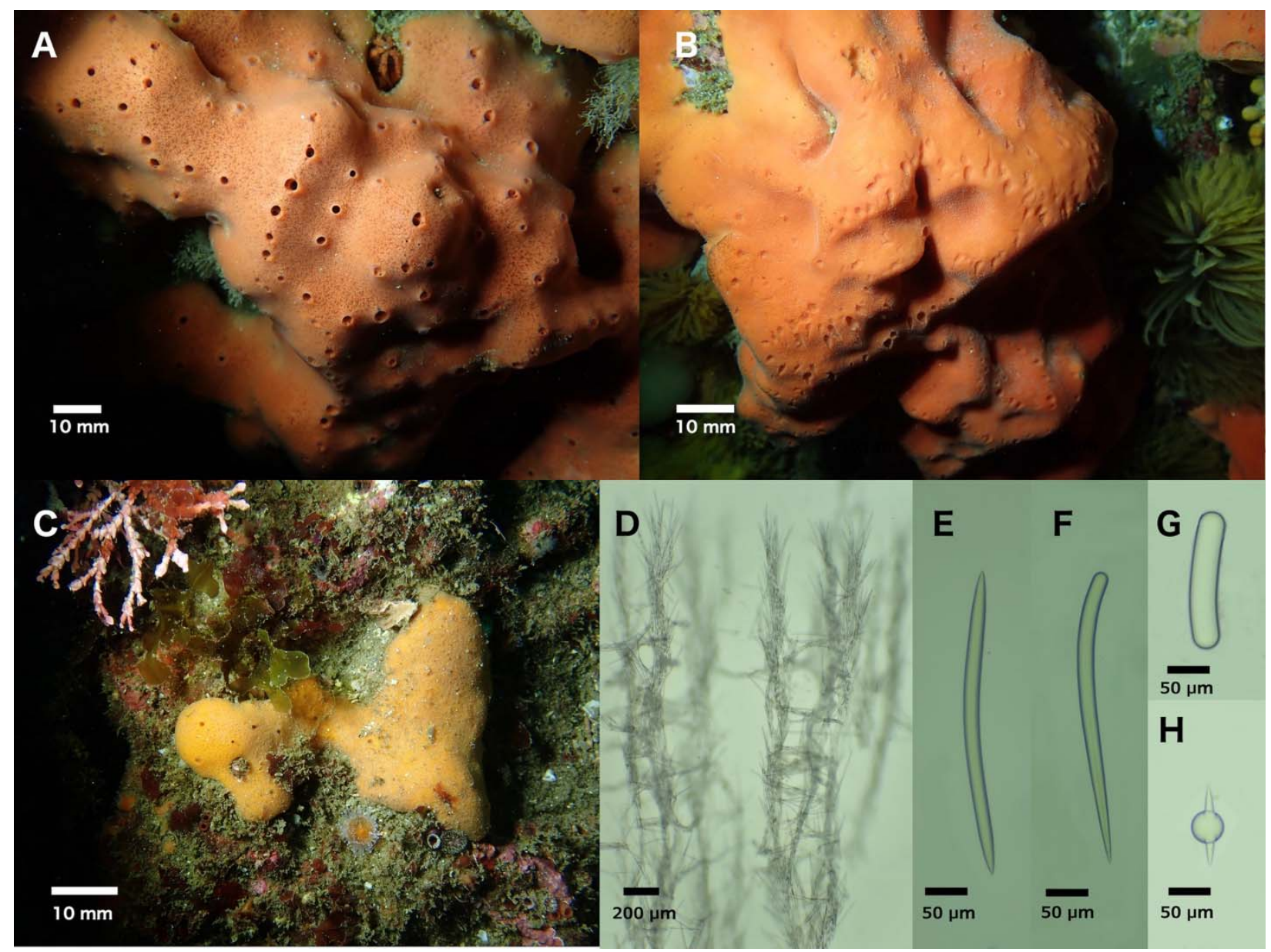

Figure 4. Dragmacidon mexicanum. A: Field photo of (TLT489, CASIZ TBD), pores and oscules open. B: Field photo of (TLT 1133, CASIZ TBD), pores and oscules closed. C: Field photo of rare yellow individual (TLT 363, CASIZ TBD), pores and oscules open for left portion only. D: Skeletal structure of (TLT489, CASIZ TBD), brushes at top pierced surface of sponge. E-F: Oxea and style from (TLT253, CASIZ TBD). G: Capsule from (TLT1133, CASIZ TBD). H: Sphere from (TLT515, CASIZ TBD).

Axinella mexicana (Dickinson 1945; de Laubenfels 1935)

Axinella sp. (Preston et al. 1996)

Pseudaxinalla mexicana (Gómez et al. 2002)

Dragmacidon mexicanum (Sim \& Bakus 1986)

?Dragmacidon sp. (Lee et al. 2007a)

Material examined. TLT 5 (CASIZ TBD) and TLT 16 (CASIZ TBD), Elwood Reef, Santa Barbara (34.41775, -119.90150), 9-15 m, 4/17/2019, collected by TT; TLT 63 (CASIZ TBD) and TLT 64 (CASIZ TBD), Landslide Cove, Anacapa Island (34.01539, -119.43560), 7-11 m, 4/25/2019, collected by SP \& TT; TLT 73 (CASIZ TBD), West End, Anacapa Island (34.01352, 
-119.44570), 7-11 m, 4/25/2019, collected by SP \& TT; TLT 447 (CASIZ TBD), Otter Cove, Monterey (36.62920, -121.92031), 7-12 m, 11/24/2019, collected by TT; TLT 489 (CASIZ TBD), TLT 501 (CASIZ TBD), and TLT 564 (CASIZ TBD), Big Rock, Santa Cruz Island (34.05220, -119.57360), 9-14 m, 1/19/2020, collected by TT; TLT 515 (CASIZ TBD) and TLT 630 (CASIZ TBD), Goalpost, Point Loma, San Diego (32.69438, -117.26860), 12-15 m, 2/8/2020, collected by TT; TLT 363 (CASIZ TBD), Dino Head, Point Loma, San Diego (32.68808, -117.27080), 21-26 m, 9/19/2020, collected by TT; TLT 957 (CASIZ TBD), Farnsworth Bank, Catalina Island (33.34380, -118.51650), 21-27 m, 7/10/2021, collected by TT; TLT 1159, CRABS, Monterey (36.55377, -121.9384), 10-17 m, 9/21/2021, collected by TT; TLT 1186 and TLT 1133, Honeymooners, Carmel Bay, Monterey (36.50390, -121.94100), 10-20 m, 9/22/2021, collected by TT; TLT 1198, Cannery Row, Monterey (36.61798, -121.8978), 9-16 m, 9/21/2021, collected by TT; TLT 253 (CASIZ TBD), Naples Reef, Santa Barbara (34.42212, -119.95154), depth not recorded, 7/15/2019, collected by Robert Miller; NHMLA 15927 / BULA-0238, Marineland, Palos Verdes, Los Angeles (33.75166667, -118.41665), depth not recorded, collected by Gustav Paulay.

Morphology. Thickly encrusting to massive, $5 \mathrm{~mm}$ to $5 \mathrm{~cm}$ thick. One of the largest shallowwater sponges in the region, with some over $60 \mathrm{~cm}$ across. Most are smooth, thick encrustations, 10-20 mm thick. Some are flat and even, others are irregular in thickness, with low undulating mounds and variable intensity of pigment. The thickest specimens up to $5 \mathrm{~cm}$ thick, massive and irregular, with prominent ridges. Nearly all are orange or orange-red externally and internally for the first 1-3 mm, and yellow in deeper tissues; a few are yellow externally and internally. All sponges fade to beige in ethanol. Surface with numerous oscules 1-2 mm in diameter, flush with surface or slightly elevated; in massive sponges, oscules occur primarily along ridges and other high points. Sponge surface between oscules is prominently patterned with a mix of opaque and transparent tissue; dermal pores (each 50-100 $\mu$ m diameter) visible in transparent regions. Oscules are closeable with a membrane, and sponges are frequently found with oscules and pores closed, in which case they appear entirely opaque and without surface patterning, often with sediment accumulating on the surface. Surface appears smooth to the eye but is microscopically hispid. Produces copious slime when cut.

Skeleton. Plumose ascending columns of styles and oxeas, chaotically bridged by oxeas. Columns pierce surface of sponge to create microscopically hispid surface.

Spicules. Styles and oxeas.

Styles: usually curved or bent near head end. Size is variable among individuals, with mean length varying from 263 to $371 \mu \mathrm{m}(\mathrm{n}=15$ sponges, $\mathrm{n}=8-27$ spicules per sponge); pooled data from all sponges $186-318-441 \times 4-13-23 \mu \mathrm{m}(\mathrm{n}=315)$.

Oxeas: usually bent in the center. Mean length per sponge varies from 315 to $380 \mu \mathrm{m}(\mathrm{n}=15$ sponges, $\mathrm{n}=7-26$ spicules per sponge); pooled data from all sponges $255-351-439 \times 3-13-23 \mu \mathrm{m}$ $(n=272)$. Oxeas are longer than styles in 14 of 15 samples, with oxea/style length ratio varying from 0.96-1.16. 
Spheroids: one sample (TLT 515) had spherical and capsule-shaped spicules, 21-65 $\mu \mathrm{m}$ in diameter, some with one or two protruding spikes. These are interpreted as an aberration.

Distribution and habitat. Common on subtidal rocky reefs throughout the investigated region (Central and Southern California) and previously known from Baja California and the Sea of Cortez (Gómez et al. 2002). This species was found at all subtidal depths investigated (5-30 m), but has not been found in the intertidal zone, or on any human-made structures (shipwrecks, oil rigs, pier pilings, or floating docks). It is especially abundant in kelp forests around Point Loma and La Jolla in San Diego County, where it was seen at all 8 sites searched. It was seen at 18 of 21 natural reefs at Anacapa and Santa Cruz Islands, but only 4 of 13 natural reefs on the mainland side of the Santa Barbara Channel. This could be due to a preference for warmer water, but based on where it was found on the mainland, we suspect it also indicates a preference for sites with lower suspended sediment. It was also common in the colder waters of Central California, as it was found at 6 of 14 subtidal sites around the Monterey Peninsula.

Discussion. This common, large, and brightly colored species is one of the most apparent subtidal sponges in Southern and Central California, and its archaeal symbionts have been a focus of past work (Preston et al. 1996). Nonetheless, the identity of this species was previously uncertain. When reviewing the literature on California sponges, Lee et al. (2007a) reported this species as "?Dragmacidon sp." because the quantitative spicule dimensions of California sponges were different from samples described from Baja California (Dickinson 1945; de Laubenfels 1935). A more recent and detailed report of samples from the Sea of Cortez matches California sponges qualitatively and quantitatively (Gómez et al. 2002). Mexican samples are reported as having oxeas only $5 \%$ longer, and styles $1 \%$ shorter than the pooled means reported here. Mexican sponges are reported as having 19\%-26\% thicker spicules than California. The data reported here are consistent with considerable variability in spicule dimensions within populations, so it seems likely that the California population fits comfortably with the named species $D$. mexicanum. Though more genotyping could reveal cryptic species, we found no evidence of any within California. Genotyped samples include the sample with the shortest spicules and two with spicules of average size, and there was no association of spicule size with geographic location. Two other species of Dragmacidon are known from the Mexican Pacific and could range into California: Dragmacidon oxeon (Dickinson 1945) and D. ophisclera (de Laubenfels 1935). Both have much longer spicules and we know of no records matching their description from California. Likewise, D. kishinense (Austin et al. 2013) is known from British Columbia and could range into California, but has much longer spicules and no California records are known.

Dragmacidon mexicanum can be tentatively identified in the field based on gross morphology alone, but spicule or DNA confirmation is advisable due to the morphological similarity of several sympatric sponges. Chief among these is Acarnus erithacus (de Laubenfels 1927). These species can often be distinguished using the more prominent surface patterning of D. mexicanum, which appears as a mesh of small pores with a maze-like pattern of opaque orange flesh below; A. erithicus is entirely opaque or with faintly visible pores. The oscula also differ, on average, with $A$. erithicus displaying oscules atop large cone or chimney-shaped projections, while $D$. mexicanum has oscules flush with the surface or slightly elevated; in large D. mexicanum oscula occur along ridges but generally not atop individual cone-shaped projections. Also, D. mexicanum is firm but yielding, while A. erithicus is rock-hard. Some 
bioRxiv preprint doi: https://doi.org/10.1101/2022.03.02 482672; this version posted March 4, 2022. The copyright holder for this preprin (which was not certified by peer review) is the author/funder, who has granted bioRxiv a license to display the preprint in perpetuity. It is made available under aCC-BY-NC-ND 4.0 International license.

sympatric Antho sp. can obtain large size and then closely resemble $D$. mexicanum, especially around the Monterey Peninsula in Central California. Like A. erithicus, these Antho sp. generally lack the prominent surface patterning between oscula.

Clint Nelson, the Dive and Boat Safety Officer for the Santa Barbara Coastal Long-Term Ecological Research Site, reports using a specific, large D. mexicanum as an underwater navigational landmark for the past 16 years, so this species is likely to be long lived.

\section{Family Raspailiidae (Nardo, 1833)}

Subfamily Raspailiinae (Nardo, 1833)

\section{Genus Endectyon (Topsent, 1920)}

\section{Endectyon (Endectyon) hyle de Laubenfels 1930}

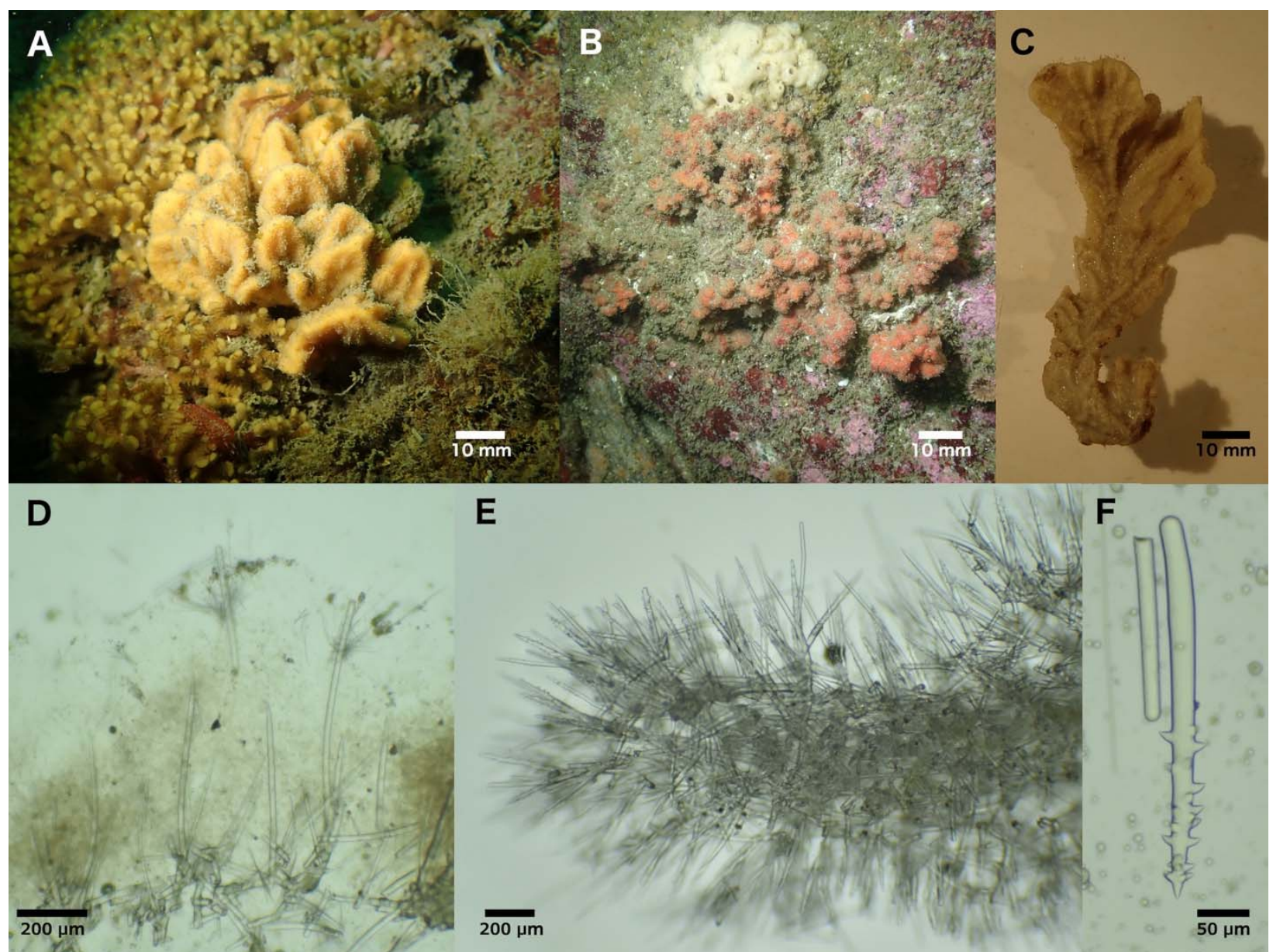

Figure 5. Endectyon hyle. Field photos of A: TLT 430 (CASIZ TBD) and B: TLT 1120 (CASIZ TBD). C: NHMLA 16545 post-preservation. D: Peripheral skeleton of TLT 411 (TBD) showing long protruding styles and ectosomal bouquets of thin styles. E: Axial skeleton with echinating acanthostyles (NHMLA 16545). F: Typical acanthostyle (TLT 1120, TBD). 
Hemectyon hyle (Bakus \& Green 1987; Dickinson 1945; Green \& Bakus 1994; de Laubenfels 1932)

Aulospongus hyle (Desqeyroux-Faundez \& van Soest 1997)

Raspailia (Raspaxilla) hyle (Aguilar-Camacho \& Carballo 2013; Hooper et al. 1999)

Endectyon (Endectyon) hyle (Lee et al. 2007a)

Material examined. TLT 284 (NHMLA 16545 / BULA-0541), Hawthorne Reef, Los Angeles, California, (33.74714, -118.42090), 24 m depth, 8/23/2019, collected by TT; TLT 411 (CASIZ TBD) and TLT 430 (CASIZ TBD), Elwood Reef, Santa Barbara, California, (34.41775, 119.90150), 10-15 m depth, 10/23/2019, collected by TT; TLT 434 (CASIZ TBD), Prince Island (near San Miguel Island), California (34.056995, -120.331089), depth not recorded, 10/8/2019, collected by Frankie Puerzer and Robert Miller; TLT 1263, Honeymooners, Monterey, California, (36.50390, -121.94100), 12-19 m depth, 9/22/21, collected by TT; TLT 1120, Cannery Row, Monterey, California, (36.61798, -121.8978), 9-15 m depth, 9/21/21, collected by TT; TLT 1179, Inner Pinnacle, Monterey, California, (36.55852, -121.96820), 18-24 m depth, 9/21/21, collected by TT.

Morphology. Growth upright but bushy, up to $6 \mathrm{~cm}$ in height. Bulky fronds extend upwards and outwards from a stalk or small base; each frond spreads along multiple axes and is usually covered in folds and corrugations. Samples usually brownish-red when alive, but one sample was yellow; samples fade to tan in ethanol. Very hispid.

Skeleton. Axially-compressed region is a dense reticulation of styles; some acanthostyles within reticulation, but most are echinating (surrounding reticulation, with heads imbedded in spongin and tips pointing outward). Long styles surround axial reticulation much like acanthostyles, but unlike acanthstyles, they pierce the sponge surface to create hispidity. Very thin styles form ectosomal bouquets in typical raspailiid fashion.

Spicules. Short styles, long styles, acanthostyles, and thin ectosomal styles; oxeas/strongyloxeas/strongyles sometimes present.

Short styles: unadorned or with weak terminal or subterminal swelling. Often curved or bent, with the bend most commonly near the head end but often in the middle; 281-454-582 x 3-12-24 $\mu \mathrm{m}(\mathrm{n}=83)$.

Long styles: usually unadorned but sometimes with weak terminal or subterminal swelling; straight or curved; 768-1065-1411 x 9-12-16 $\mu \mathrm{m}(\mathrm{n}=11)$.

Acanthostyles: occasionally bent near head but more often straight or slightly curved; spines usually limited to the half of style closer to point, but sometimes occur near or even on the head of the style. Spines large and curved towards head end of style; 90-278-394 x 2-14-20 $\mu \mathrm{m}$ $(n=64)$.

Thin ectosomal styles: 226-350-768 x 1-3-5 $\mu \mathrm{m}(\mathrm{n}=20)$. 
Oxeas/strongyloxeas/strongyles: present in some samples; dimensions similar to styles but often show two bends instead of one bend or a curve; 502-572-657 x 8-13-17 $\mu \mathrm{m}(\mathrm{n}=12)$.

Distribution and habitat. Published occurrences range from British Columbia (Austin 1985) to the Gulf of California (Dickenson), and from $15 \mathrm{~m}$ to $330 \mathrm{~m}$ in depth (Luke 1998). We found this species only rarely on shallow $(<15 \mathrm{~m})$ rocky reefs, where most search effort was concentrated, but more frequently on deeper $(24-30 \mathrm{~m})$ reefs. It was found in multiple previous surveys around Southern California, with some samples reportedly as shallow as $15 \mathrm{~m}$ (sample CASIZ 182375, Santa Rosa Island) but most "shallow" samples were collected below 20 m (Luke 1998). It has been found in multiple deep-water surveys far below diving depths in Southern California (Bakus \& Green 1987; Green \& Bakus 1994), with the deepest record at $330 \mathrm{~m}$ in La Jolla, San Diego (Luke 1998). We therefore hypothesize that it is common from deep water up to $20 \mathrm{~m}$ and uncommon in shallower water.

\section{Discussion.}

The morphology and spiculation of E. hyle have been described in previous work (AguilarCamacho \& Carballo 2013; Hooper et al. 1999). The freshly collected samples described here differ from previous descriptions in the nature of the ectosomal skeleton, which was previously described as vestigial, with thin styles tangential rather than in typical raspailiid brushes associated with protruding styles (Aguilar-Camacho \& Carballo 2013; Hooper et al. 1999). We found typical raspailiid brushes, so this character is likely variable. Previous authors noted other variable traits as well, such as spicular dimensions and whether or not long styles are common (Aguilar-Camacho \& Carballo 2013). The only sample described from the Gulf of California, in Mexico, also differs from all others in that it is "ramose" (two cylindrical branches), while all others are stalked and frondulose (the Mexican specimen is not an outlier with respect to spiculation). The type location for this species is the Palos Verdes Peninsula, and one of the samples sequenced here (CASIZ TBD) is from this location. It would therefore be valuable to collect additional genetic data from Mexico and from deep-water samples to confirm conspecificity with the shallow-water E. hyle in California.

Endectyon hyle has been difficult for taxonomists to place. It was initially described as a Hymectyon (de Laubenfels 1932), which is now considered a subgenus of Endectyon. It was later described as both an Aulospongus (Desqeyroux-Faundez \& van Soest 1997) and Raspailia (Raspaxilla) (Hooper et al. 1999), based largely on the supposed presence of rhabdostyles. We find that nearly all acanthostyles in this species lack a bend near the head, and this is in fact consistent with previously published images of this spicule in this species (Hooper et al. 1999). In addition, de Laubenfels noted that the acanthostyles were located mainly in the periphery, which is now considered a trait of Endectyon. Moreover, the styles bear large, recurved spines, also a characteristic of Endectyon. Likely for these reasons, Lee et al. (2007a) described the species as a member of Endectyon (Endectyon). We agree that this placement is most consistent with the morphological characters. With additional support from the DNA phylogenies, we propose this species be placed in Endectyon (Endectyon), pending a more systematic revision of the entire family.

Most samples of $E$. hyle found in California are probably identifiable in the field based on gross morphology alone. The most similar species is Trikentrion helium, which is also reddishbrown, stalked, and frondulose. Samples of T. helium differ by having large laminate fronds, each growing mostly in a single plane and lacking corrugations and wrinkles; E. hyle fronds are 
bioRxiv preprint doi: https://doi.org/10.1101/2022.03.02.482672; this version posted March 4, 2022. The copyright holder for this preprint (which was not certified by peer review) is the author/funder, who has granted bioRxiv a license to display the preprint in perpetuity. It is made available under aCC-BY-NC-ND 4.0 International license.

short, rugose and bushy, with multiple axes in a tangential section. However, the type specimen of $T$. helium (van Soest et al. 2012, fig. 24) appears somewhat bushy, likely because it was young and/or small, without extended blades. Further field work on the living morphology of these species is therefore warranted. Several small samples of E. hyle were also found that were short, rounded, and lumpy; these could be confused with $C$. neon in the field, though $C$. neon looks fleshier.

\section{Endectyon (Endectyon) hispitumula sp. nov.}

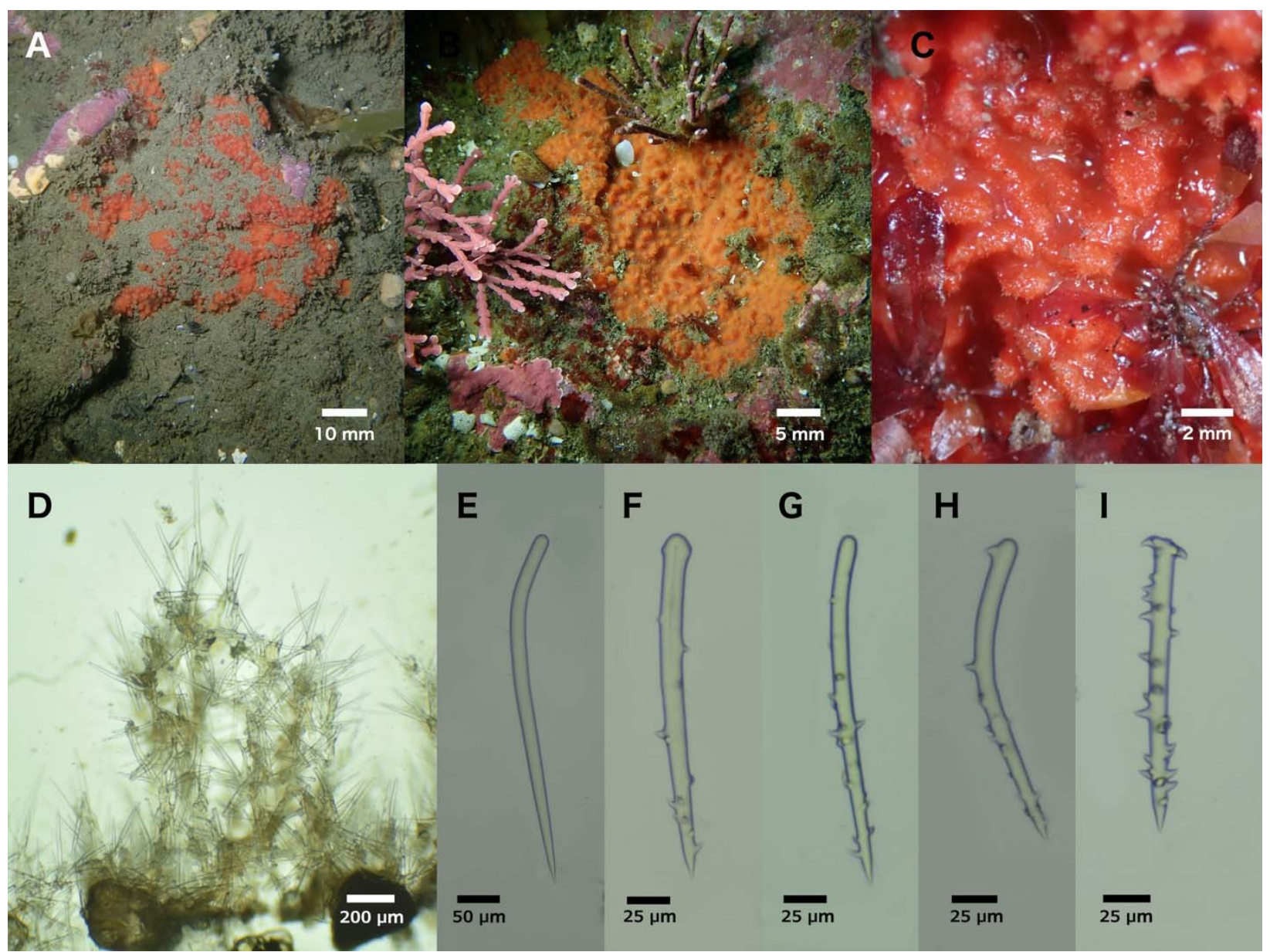

Figure 6. Endectyon hispitumula. Field photos of A: holotype (TLT453, TBD) and B: paratype (TLT517, TBD); C: Field photo of intertidal paratype (TLT587, TBD). D: Skeletal structure of TLT517 (TBD). E: typical style from holotype. F-I: Spectrum of acanthostyle morphology; F-H from holotype, G from paratype TLT632 (TBD), I from paratype TLT517 (TBD).

Material examined. Holotype: TLT 453 (CASIZ TBD), Coal Oil Point, Santa Barbara, California (34.40450, -119.87890), depth 3-6 m, 10/28/2019. Other samples: TLT 859 (CASIZ TBD) and TLT 827 (CASIZ TBD), Cave Landings, San Luis Obispo, California (35.17535, 120.72240), intertidal, 2/6/2021; TLT 190 (CASIZ TBD), Arroyo Hondo, Santa Barbara, California (34.47182, -120.14262), depth 4-8 m, 7/29/19; TLT 239 (CASIZ TBD), Naples Reef, Santa Barbara, California (34.42212, -119.95154), depth 10-15 m, 7/31/2019; TLT 69 (CASIZ TBD), West End of Anacapa Island, California (34.01352, -119.44570), depth 7-12 m, 
4/25/2019; TLT 587 (CASIZ TBD), Lechuza Point, Ventura, California (34.03437, -118.86146), intertidal, 12/14/2020; TLT 517 (CASIZ TBD) and TLT 632 (CASIZ TBD), Goalpost Reef, San Diego, California (32.69438, -117.26860), depth 12-15 m, 2/8/2020; all samples collected by TT.

Etymology. From the latin hispidus (bristled) and tumulus (mound).

Morphology. Thinly encrusting: the holotype is $5 \mathrm{~mm}$ thick, other samples 3-10 $\mathrm{mm}$ thick. Appearance usually evokes a rolling field of hills, like a barrow field; each hill is hispid, with smooth membranous depressions stretched between them. The thickest samples have deeper furrows between hispid mounds, such that they are more like hispid columns; in these cases, a tangential cut through the sponge results in the sponge nearly falling apart into separate columns. Orange-red alive, like many other Axinellid and Microcionid sponges in the same habitats. Fades to cream/white in ethanol.

Skeleton. Nodes of spongin ascend from a basal spongin mat, and both are sometimes cored with sediment. The basal mat contains a reticulation of smooth styles; this reticulation extends up from the mat in plumoreticulate columns bound with considerable spongin. Columns are echinated with smooth styles whose heads are embedded in spongin but are otherwise free; most echinating spicules are angled up giving the columns a columnar-cactus-like aspect.

Plumoreticulated columns pierce the surface of the sponge to create hispid mounds; smaller and shorter reticulated columns are found between hispid mounds. Thin hair-like styles are embedded tangentially in the ectosome, singly or in bundles. Acanthostyles are present in the holotype but frequently absent in other samples. When present, they are found primarily with heads embedded in the basal spongin mat, tips up; some are also found echinating plumose columns.

Spicules. Styles, acanthostyles, and thin ectosomal styles.

Styles: Generally curved or bent near head end; could perhaps be characterized as rhabdostyles, but this seems subjective. Size is variable among samples, with mean lengths varying from 254 $\mu \mathrm{m}$ to $403 \mu \mathrm{m}(\mathrm{n}=20-49$ per sample); mean width varies from $8.8 \mu \mathrm{m}$ to $16 \mu \mathrm{m}$ per sample. Holotype: $327-403-472$ x 9-16-20 $\mu \mathrm{m}(\mathrm{n}=21)$. Combined distribution from all samples: $127-$ 330-698 x 2-12-23 $\mu \mathrm{m}(\mathrm{n}=271)$. One sample contained two oxeas.

Acanthostyles: Generally straight but sometimes curved. Not likely to be characterized as rhabdostyles, as none show sharp bend near the head. Spines are often large and recurved, and are most dense at tip end but occur all the way to the head of style. Present in only 5 of 9 samples. Mean size per sample from 151 to $171 \mu \mathrm{m}$ in length, 9 to $12 \mu \mathrm{m}$ in width; holotype 133175-210 x 9-12-14 $\mu \mathrm{m}(\mathrm{n}=21)$; combined distribution from all samples 118-166-224 x 6-11-20 $\mu \mathrm{m}(\mathrm{n}=62)$. One sample contained a single acanthoxea.

Thin ectosomal styles: Very thin and usually broken; 133-196-332 x 1-3-4 $\mu \mathrm{m}(\mathrm{n}=22)$.

Distribution and habitat. Known range is from Avila Beach, San Luis Obispo County, Central California to Point Loma, San Diego County, Southern California, which is the Southernmost area investigated. A sponge photographed by Alison Young (California Academy of Sciences) at 
Yerba Buena Island, in San Francisco Bay, appears to be this species based on external morphology, so it may range into Northern California as well (inaturalist.org/observations/75598358).

This species is common in shady intertidal crevices, and it seems especially abundant in the intertidal zone along the Malibu coastline in Southern California. Subtidally, it is common in very shallow water $(<10 \mathrm{~m})$, with a maximum collection depth of $15 \mathrm{~m}$. It primarily grows on or under ledges in the subtidal, but is also found in the open, including in areas with high sedimentation where it can be found partially buried by sand.

Discussion. This species should be placed in the subfamily Raspailiinae as it lacks the features characteristic of other raspailiid subfamilies. Placement in a genus is more difficult. Most encrusting species are placed in Hymeraphia (which can be excluded based on acanthostyle morphology) or Eurypon. Eurypon have a microcionid or hymedesmoiid skeleton, whereas $E$. hispitumula is reticulated. The large, recurved spines on the acanthostyles are consistent with Endectyon, as is the close relationship with E. hyle, E. delaubenfelsi, and E. fruticosum.

Though the spiculation of this species varies among samples, there is no evidence to support subdivision into multiple taxa. Samples that lack acanthostyles do not differ from those that have them in terms of primary style size or other characters. Samples with DNA data include those with the longest and shortest styles, two with acanthostyles and two without, and samples spanning the Southern California portion of the range (Point Loma, Anacapa Island, Coal Oil Point, Arroyo Hondo); these DNA data contain no evidence for multiple species.

Though there are many orange/red encrusting sponges in California, the "hispid mound field" morphology often makes this species distinguishable in the field. This makes it all the more surprising that it has not been reported in any previous survey in California (Lee et al. 2007a). No described species nor undescribed morphospecies is similar to this species, despite considerable work in the Central California intertidal sponge fauna (Hartman 1975) and some surveys in Southern California (Bakus \& Green 1987; Sim \& Bakus 1986). It is therefore temping to speculate that this species is more common in this region today than in the recent past. 


\section{Genus Raspailia (Nardo, 1833)}

\section{Raspailia (Raspaxilla) hymani Dickenson 1945}

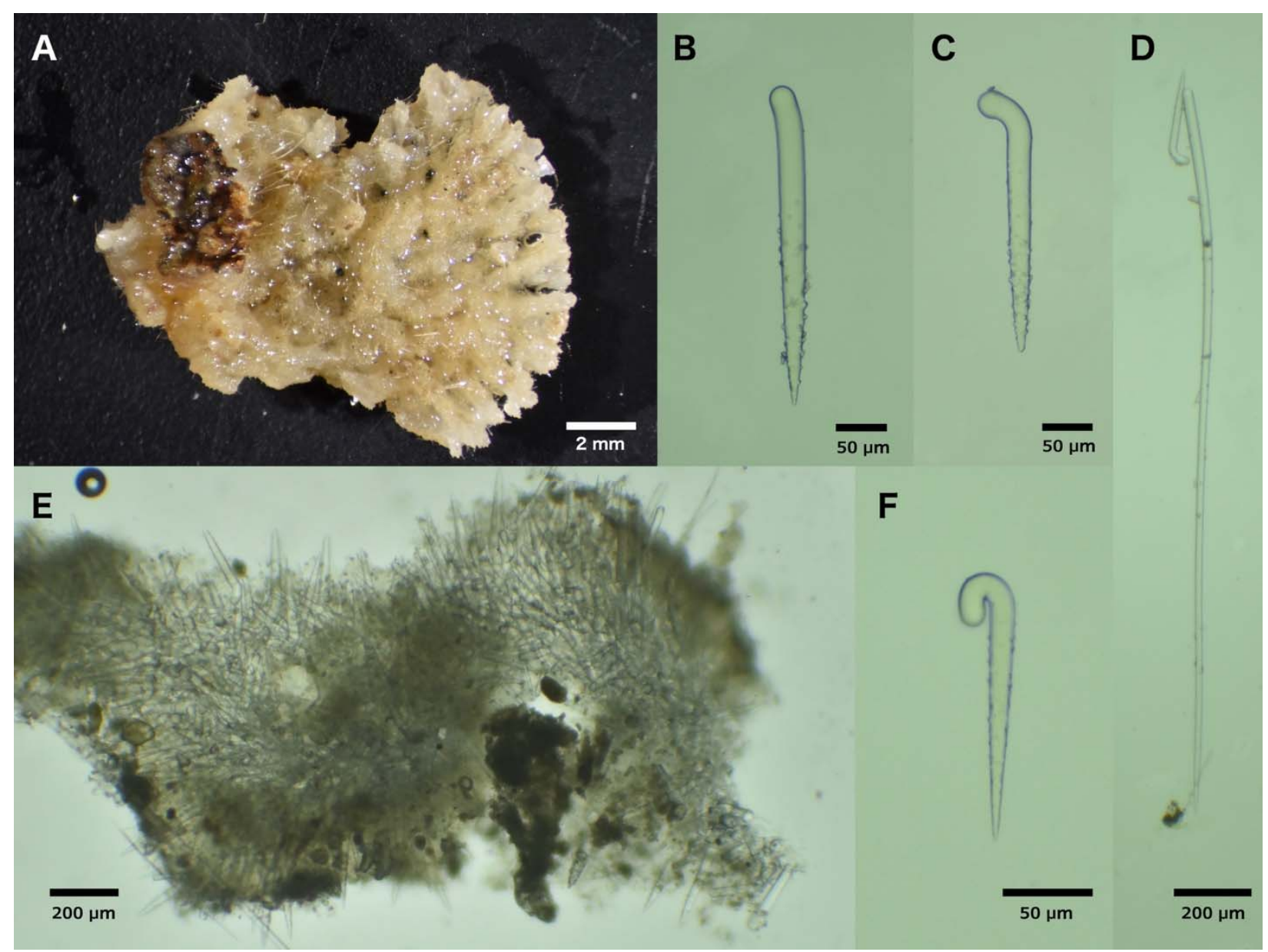

Figure 7. Raspailia hymani. A: Preserved sample. B-C, F: Spectrum of acanthostyle morphology. E: Skeletal structure. F: Long style with acanthostyle. All photos of sample SBMNH 467982.

Raspailia (Raspaxilla) hymani (Aguilar-Camacho \& Carballo 2013; Hooper et al. 1999) Endectyon (Endectyon) hymani (Lee et al. 2007a)

Aulospongus hymani (Desqeyroux-Faundez \& van Soest 1997)

Hemectyon hymani (Dickinson 1945; Green \& Bakus 1994)

Material Examined. SBMNH 467982, Off Purisima Point, Santa Barbara (34.7757, -120.8367), 91-123 m depth, 7/23/1984, collected by Don Cadien.

Morphology. Growth mostly in a single plane, 13 x $11 \mathrm{~mm}$. Surface a network of bundles 500$600 \mu \mathrm{m}$ wide, forming a lattice-like pattern, fanning out towards distal end. Beige in ethanol, color alive unknown. 
Skeleton. Choanosome contains a very dense reticulation of rhabdotyles, echinated by same. Long plain styles emerge from this axially compressed skeleton to pierce the surface of the sponge and extend up to $1700 \mu \mathrm{m}$ past sponge surface. Thin styles also protruding from ectosome singly or in small groups, but characteristic raspailiid brush-like pattern not seen.

Spicules. Long styles, acanthorhabdostyles, and thin styles.

Long styles: Gently curved or slightly sinuous, but not bent. 1333-1810-2157 x 26-27-30 $\mu \mathrm{m}$ $(\mathrm{n}=5)$.

Acanthorhabdostyles: Most have heads sharply bent at a 45-90 angle from shaft. Some have heads bent 180 degrees to form complete u-shaped head region, while a minority are straight. Spines are usually limited to the pointed half of the style but some are completely spined and some unspined. Size varies greatly in a continuous but bimodal distribution (modes at 175 and $305 \mu \mathrm{m}$ ). If separated into categories at $270 \mu \mathrm{m}$ (following (Aguilar-Camacho \& Carballo 2013)), size distributions are 122-183-260 x 8-16-26 $\mu \mathrm{m}(\mathrm{n}=59)$ and 272-313-384 x 21-27-32 $\mu \mathrm{m}$ $(\mathrm{n}=23)$; combined distribution 122-220-384 x 8-19-32 $\mu \mathrm{m}(\mathrm{n}=82)$.

Thin styles: Gently curved or slightly sinuous, but not bent. 498-601-967 x 3-5-9-6 $\mu \mathrm{m}(\mathrm{n}=10)$.

Distribution and habitat. Only known from deep water, 90-138 $\mathrm{m}$ depth, from Purisima point (just North of the Southern California Bight) to Isla Partida, Cabo San Lucas, Mexico.

Discussion. This specimen, previously examined by Green and Bakus (1994), is one of two specimens known from California. It differs from the published descriptions of two Mexican specimens in several respects including width of the lattice-like network of thickened sections (approximately 500-600 $\mu \mathrm{m}$ wide in California, 1200-2000 $\mu \mathrm{m}$ wide in Mexico based on figure 1 of (Aguilar-Camacho \& Carballo 2013)) and the length of the thin ectosomal styles. Most notably, the very long protruding styles that are prominent in the California specimen are not mentioned and presumed absent in the Mexican samples. This difference is similar to the variation reported above in E. hyle, and the similarities between the California and Mexican material are notable. All samples are fan shaped with a lattice-like pattern of ridges, and have acanthostyles that are severely bent at the head. Splitting the size distribution of acanthosyles in the same way as Aguilar-Camacho and Carballo (2013) leads to very similar size distributions in both size bins. We therefore think it is likely that the California and Mexican samples are of the same species. DNA extractions were attempted but did not yield PCR amplifiable DNA. 


\section{Genus Eurypon (Gray, 1867)}

\section{Eurypon curvoclavus sp. nov.}

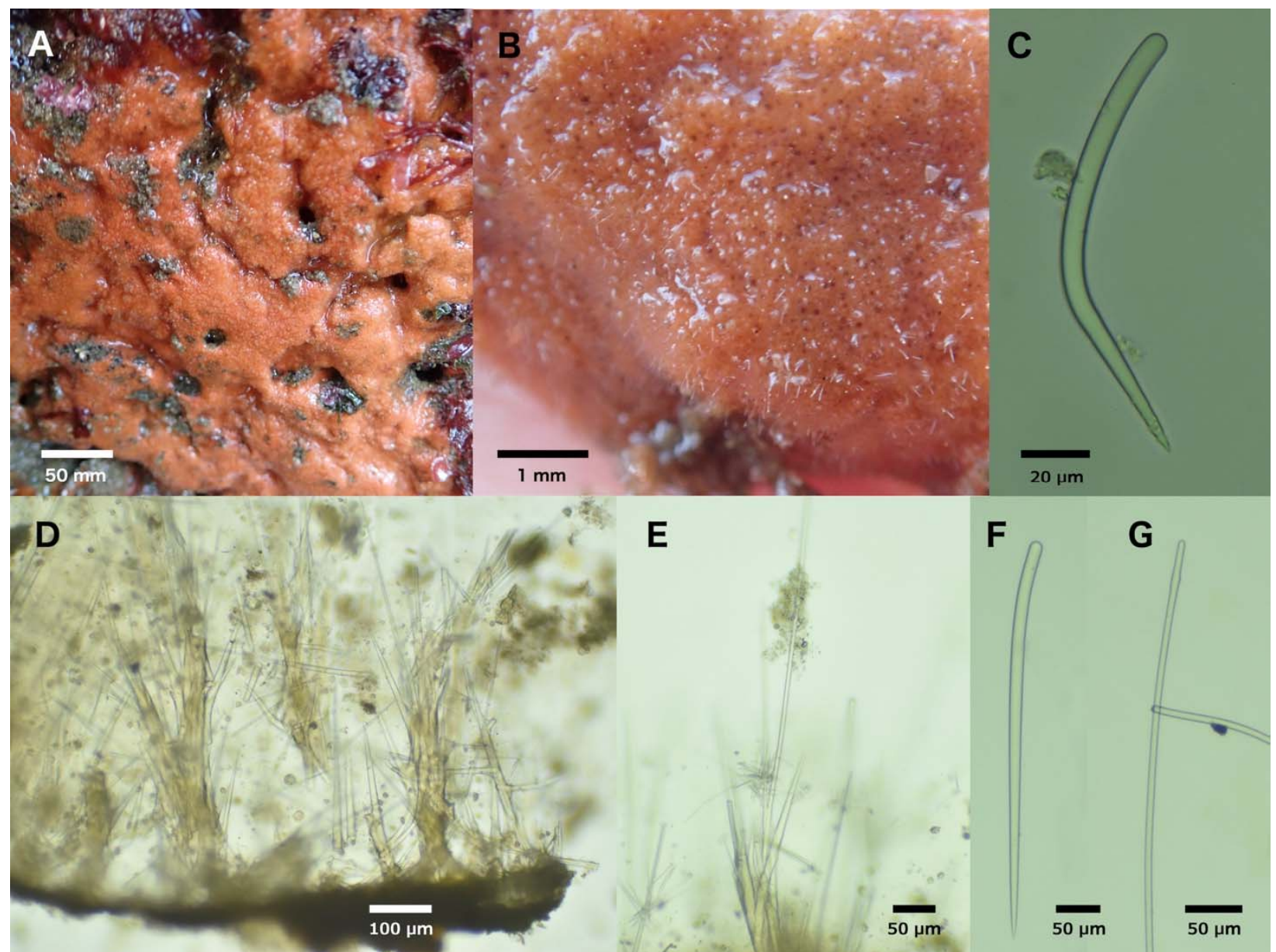

Figure 8. Field photos of A: holotype (TLT 799, TBD) and B: paratype (TLT 784, TBD), both exposed at low tide. C: Acanthostyle from paratype (TLT 775, TBD). D: Tangential section showing spongin nodes arising from basal plate. E: Peripheral skeleton with long protruding style surrounded by ectosomal bouquet. F: Style. G: Long style. D-G from holotype.

Material examined. Holotype TLT 799 (CASIZ TBD); other samples TLT 775 (CASIZ TBD), TLT 784 (CASIZ TBD); all collected by TT at Bird Rock, San Diego, California, USA (32.81447, -117.274313), in the intertidal zone, 1/10/2021.

Etymology. The distinctly curved acanthostyles resemble bent (curvus) nails (clavus).

Morphology. Thinly encrusting. Holotype approximately 6 x $6 \mathrm{~cm}, 1 \mathrm{~mm}$ thick; other samples $2-6 \mathrm{~cm}$ across, $0.5-1 \mathrm{~mm}$ thick. Surface fairly flat, not particularly rugose, but varying thickness makes the surface slightly undulating. Covered in small pores of varying size, from about 20-100 $\mu \mathrm{m}$ in diameter. Visibly hispid due to long protruding styles. Reddish orange when alive, beige when preserved in ethanol. 
Skeleton. Sponge contains a basal plate of spongin with many acanthostyles embedded within. Vertical trunks of spongin arise from the basal plate and are cored with styles; some styles have tips free, making columns plumose. Columns are echinated with acanthostyles and sometimes bridged by horizontal tracks of spongin cored with styles. Long thin styles are embedded near the tops of some columns; these pierce the surface of the sponge and make the surface hispid. Thin ectosomal styles fan out in brushes around these protruding styles, creating the typical raspailiid ectosomal skeleton.

Spicules. Styles, acanthostyles, and thin ectosomal styles.

Styles: straight, slightly curved, or weakly bent; if bent, bend is near head end, unlike acanthostyles. Average length varies from 131 to $350 \mu \mathrm{m}$; holotype: $238-350-520$ x 5-10-13 $\mu \mathrm{m}$ $(\mathrm{n}=23)$; all samples pooled: 193-338-633 x 5-10-14 $\mu \mathrm{m}(\mathrm{n}=55)$.

Thin styles: straight or gently curved; sometimes with weak subterminal swelling near head. Generally longer and thinner than coring styles, but size classes are hard to clearly separate and likely overlap. Dimensions in holotype: 550-676-945 x 3-5-6 $\mu \mathrm{m}(\mathrm{n}=8)$; all samples pooled: 491760-994 x 3-5-8 $\mu \mathrm{m}(\mathrm{n}=21)$.

Echinating acanthostyles: most are sharply bent; in contrast to rhabdostyles, bend is usually between $50 \%$ and $66 \%$ of the way towards tip. Many are weakly spined near tip only, some appear completely unspined; rarely $(<1 \%)$ modified to oxeas. When measured in a straight line from head to tip, dimensions in holotype are 106-135-166 x 4-6-10 $\mu \mathrm{m}(\mathrm{n}=33)$; all samples pooled: 84-127-215 x 3-6-12 $\mu \mathrm{m}(\mathrm{n}=99)$; average lengths for each sponge individually $=112$, $133,135 \mu \mathrm{m}$. If lengths are measured along the curve, lengths increase approximately $10 \%$.

Hair-like styles: only 1-2 microns thick, lengths from 100-500 $\mu \mathrm{m}$, but most were broken and likely longer in life.

Distribution and habitat. All samples were found on short rock walls or under ledges, exposed at low tide, at Bird Rock in San Diego. Three samples were found in less than an hour of searching, so it seems to be abundant at this location. As it was not reported in previous surveys in California (Bakus \& Green 1987; Hartman 1975; de Laubenfels 1932), nor found at any other location in the current work, nor reported from surveys in Mexico (Carballo et al. 2019; Gómez et al. 2002; Hofknecht 1978), it doesn't seem to be common at many other locations.

Discussion. The ectosomal skeleton, echinating spicules, and lack of polyactines place this species in the subfamily Raspailiinae. The encrusting morphology of this sponge, with its "microcionid" skeletal structure (fiber nodes ascending from a basal layer of spongin) are most consistent with placement in the genus Eurypon. Eurypon are defined as "typically encrusting Raspailiidae with microcionid skeletal structure in which fiber nodes ascend from the basal layer of spongin" (Hooper 2002c). Many of the described species lack these ascending fiber nodes, and instead have a "hymedesmoid" skeletal structure of spicules embedded directly in the basal spongin, tips up (Aguilar-Camacho \& Carballo 2013; Cavalcanti et al. 2018; Santos et al. 2014). This variable skeletal structure may be related to the thickness of the species (Santos et al. 2014). Previous molecular phylogenies of multiple loci found Eurypon to be polyphyletic (Redmond et 
bioRxiv preprint doi: https://doi.org/10.1101/2022.03.02.482672; this version posted March 4 , 2022. The copyright holder for this preprin (which was not certified by peer review) is the author/funder, who has granted bioRxiv a license to display the preprint in perpetuity. It is made available under aCC-BY-NC-ND 4.0 International license.

al. 2013; Thacker et al. 2013), which is also found in our updated phylogenies. A revision of the genus awaits genetic data from more species and a better resolved phylogenetic tree.

The bent echinating styles differentiate this species from all described species of Eurypon, as listed by Recinos et al. (2020). There are also four species of encrusting Raspailiinae described in the genus Hymeraphia, though none are known from the Pacific; all Hymeraphia greatly differ from the newly described species in echinating style morphology and skeletal architecture (Morrow et al. 2018).

No other Eurypon have been described from California; the closest records are several Eurypon with a more hymedesmoid architecture known from the tropical Mexican Pacific (Aguilar-Camacho \& Carballo 2013). A "Eurypon? sp." was also listed as occurring in British Columbia, but with no published data on its morphology (Austin 1985).

Identifying this species in the field would be challenging, as there are many thinly encrusting intertidal Microcionidae in California; the smooth, non-rugose surface of this sponge is very similar to sympatric Clathria such as $C$. originalis. These Clathria lack the long protruding styles, which are visible in good macro photos of live colonies; Cyamon koltuni are not known from the intertidal, but are also hispid with protruding styles.

\section{Genus Aulospongus (Norman, 1878)}

Aulospongus viridans sp. nov.

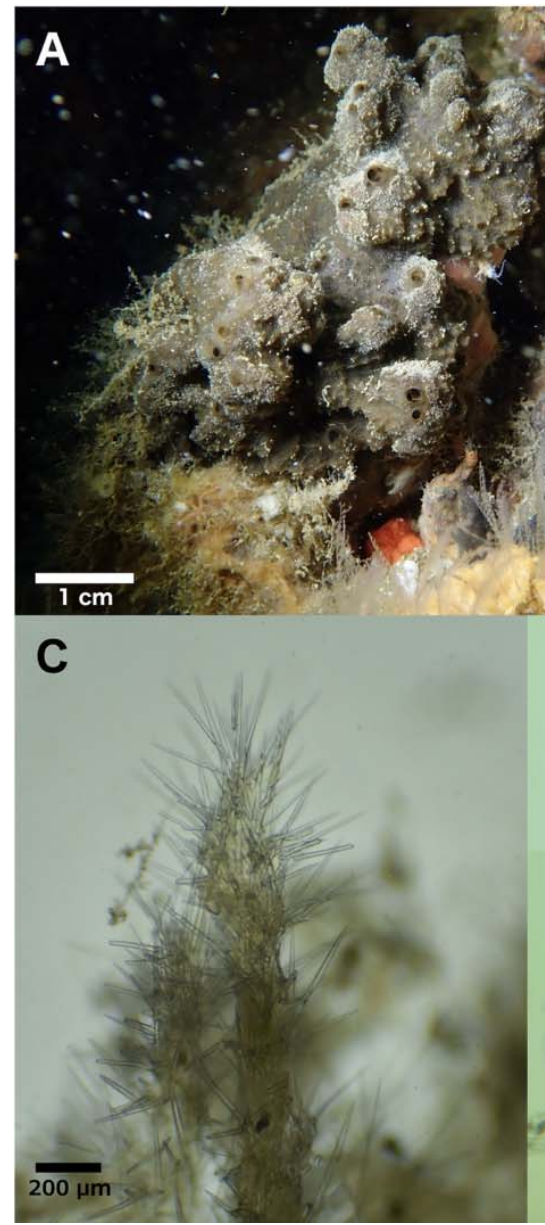

B

D
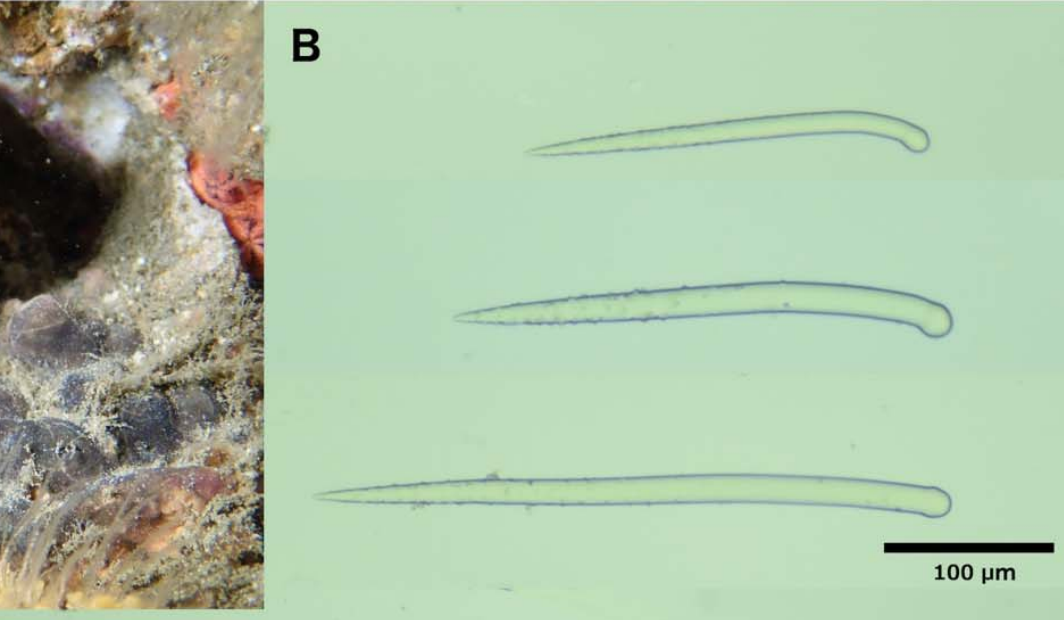

$\mathbf{E}$

$100 \mu \mathrm{m}$ 
Figure 9. Aulospongus viridans. A: Field photo. B: Spectrum of morphology found in acanthostyles. C: Skeletal structure. D: Long subectosomal style. E: Ectosomal bouquets and surface debris. All photos from holotype, TLT500, TBD.

Material examined. Holotype: TLT 500 (CASIZ TBD), Big Rock, Santa Cruz Island, California, USA (34.05220, -119.57360), 6-14 m depth, 1/19/2020.

Etymology. From the latin viridis, meaning green.

Morphology. Massive and irregular, approximately 5 x 3 x $2 \mathrm{~cm}$. Surface covered in prominent conules, with oscula concentrated at high points. Dark green in life, it retains its pigmentation in ethanol. Surface membrane is opaque after preservation, but in life it is a mix of opaque regions and regions with a visible mesh of pores.

Skeleton. Choanosome contains plumose ascending tracts of spongin cored with styles, 50 - 250 $\mu \mathrm{m}$ thick, becoming less dense at the periphery. Tracts are echinated by spined and unspined styles. Coring styles tend to be longer, straighter, less tylote and less spined, on average, but this is not absolute. Long subectosomal styles pierce the ectosome and thin ectosomal oxeas form brushes that pierce the surface.

Spicules. Rhabdostyles, long subectosomal styles, and thin ectosomal styles.

Rhabdostyles: usually with a terminal tyle, but sometimes with a subterminal bulge, polytylote, or plain. Spines are small when present, and usually limited to the pointed half of the style, but many are entirely smooth. Spined and unspined rhabdostyles are difficult to separate, as some are very weakly spined; when pooled, the length distribution is bimodal, with modes at 215 and 315 $\mu \mathrm{m}$. Acanthorhabdotyles alone: 103-249-420 x 3-11-17 $\mu \mathrm{m}(\mathrm{n}=109)$; unspined rhabdostyles alone: $156-300-528$ x 5-10-14 $\mu \mathrm{m}(\mathrm{n}=30)$; Wilcox rank-sum test indicates acanthose may be smaller $(\mathrm{p}=0.06)$.

Subectosomal styles: sometimes curved or bent but generally lacking sharp bend of rhabdostyles and most lack tyle; 565-839-1091 x 5-10-15 $\mu \mathrm{m}(\mathrm{n}=12)$.

Ectosomal styles/strongyloxeas: Thin ectosomal styles most common, but some are fusiform and some pointed at both ends; 246-456-679 x 2-3-5 $\mu \mathrm{m}(\mathrm{n}=34)$.

Distribution and habitat. The holotype is the only sample found to date. Found at the Big Rock dive site on Santa Cruz Island, which is a sheltered cove with shallow rocky reef and kelp forest. The sponge was found in a shaded crevice among large boulders.

Discussion. Raspailiidae with rhabdostyles are currently allocated to three taxa: Aulospongus, Raspailia (Raspaxilla), and Endectyon (Hemectyon). In Raspaxilla and Hemectyon, fibres are cored by smooth, non-rhabdose styles (Hooper 2002c). We find the distinction between rhabdostyle and non-rhabdose bent or curved styles to be subjective, and more of a spectrum than distinguishable categories. In the case of $A$. viridans, however, the distinctly asymmetric tyle found on both coring and echinating styles seems likely to fall on the rhabdostyle end of the 
bioRxiv preprint doi: https://doi.org/10.1101/2022.03.02.482672; this version posted March 4, 2022. The copyright holder for this preprint (which was not certified by peer review) is the author/funder, who has granted bioRxiv a license to display the preprint in perpetuity. It is made available under aCC-BY-NC-ND 4.0 International license.

spectrum, and it is found in large unspined styles and smaller ones that are entirely spined. This sponge also lacks distinction between axial and extra-axial skeleton, and the plumose ascending tracts are more dendritic than reticulated, and both these traits are also more consistent with Aulospongus than Raspaxilla or Hemectyon (Hooper et al. 1999).

Though describing a new species from a single sample is not ideal, the characteristics of this sponge are distinctive enough that it is unlikely to be conspecific with any known species. The green color of this sponge, and the fact that it retains its pigmentation in ethanol, are in contrast to all other sponges described herein. This color also sets it apart from all known species of Aulospongus (and Raspaxilla). Three species of Aulospongus have been described from the Pacific, all from Mexico. Two, A. cerebella (Dickinson 1945) and A. californianus (AguilarCamacho \& Carballo 2013), are deep sea species, pale beige in ethanol, tubular or vase-shaped, and have much thicker styles. The final Pacific species, A. aurantiacus (Aguilar-Camacho \& Carballo 2013), is known from shallow water but is orange, encrusting, and lacks a raspailiid ectosomal skeleton.

Subfamily Cyamoninae (Hooper, 2002)

\section{Genus Trikentrion (Ehlers, 1870)}

\section{Trikentrion helium Dickinson, 1945}

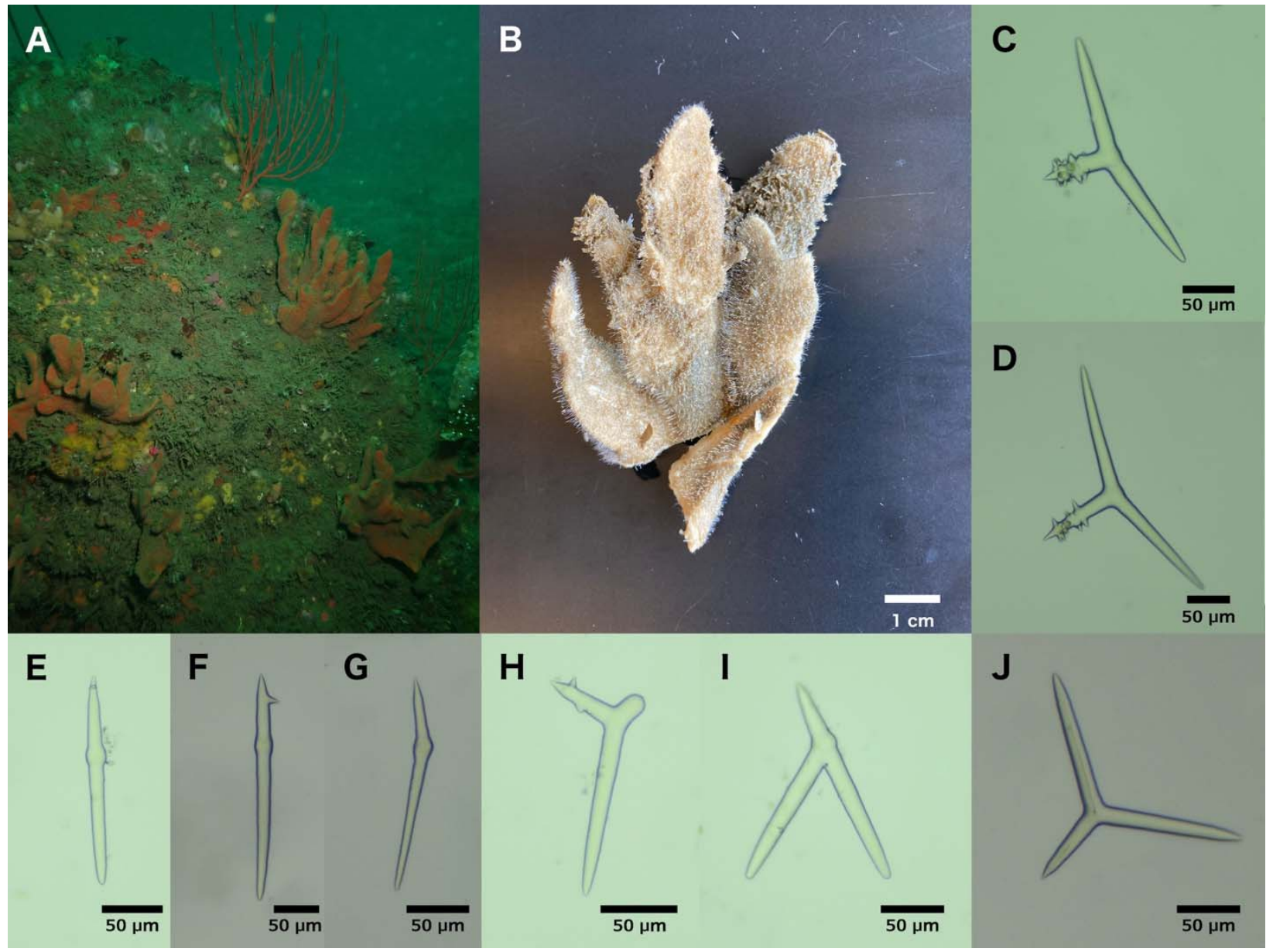


Figure 10. Trikentrion helium. A: Field photo of uncollected samples off Point Loma, San Diego, $25 \mathrm{~m}$ depth. B: Sample NHMLA (TBD) post-preservation. Spectrum of polyactine morphologies from TLT 588 (TBD) (C, I) and NHMLA (TBD) (D, H, J). Sampling of diactinal polyactines from TLT 588 (TBD) (E) and NHMLA (TBD) (F, G).

Trikentrion helium (Claisse et al. 2018; Dickinson 1945; Smith 1968; van Soest et al. 2012) Trikentrion catalina (Gómez et al. 2002; van Soest et al. 2012) Cyamon catalina (Lee et al. 2007a; Sim \& Bakus 1986)

Material examined. TLT 673 (NHMLA TBD), Hawthorne Reef, Los Angeles, California, USA (33.74714, -118.42090), 24 m depth, 8/23/2019; TLT 588 (CASIZ TBD), Trainwheels Reef, San Diego, California, USA (32.65205, -117.26243) $28 \mathrm{~m}$ depth, 9/19/2020. Both collected by TT.

Morphology. One or more thin bladed lamina (2-3 mm thick) growing from a stalk. Each leaflike blade has growth mostly in a single plane, with even thickness, lacking corrugations. Very hispid. Consistency firm and leathery. Bright red to orange-red alive, beige in ethanol.

Skeleton. A dense mass of polyactines cores each blade, surrounded by tangential styles. Long styles are perpendicular to the core, protruding from the ectosome, surrounded by typical raspialiid brushes of smaller styles.

Spicules. Long thin styles, short thin styles, polyactines, trichodragmas. Measurements shown below are from both samples combined.

Long thin styles: 1135-1709-2708 x 6-13-22 $\mu \mathrm{m}(\mathrm{n}=22)$.

Short thin styles, usually plain styles but sometimes few tylostyles; some fusiform, approaching strongyloxeas/oxeas: $364-527-673$ x 2-4-8 $\mu \mathrm{m}(\mathrm{n}=24)$.

Polyactines: predominantly triactines with one shorter (basal) cladus which usually bears prominent spines and two lateral clades which are unspined. Shape often sagittal, with unspined clades at a 180-degree angle. Variation is considerable, with many triactines at various angles, sometimes entirely unspined, and with length of clades deviating from the typical pattern. Occasional tetractinal polyactines. Diactinal polyactines numerous and diverse in shape. Many have one cladus replaced with a knob, while others have two clades. The two clades may be at an angle or straight; when straight the shape is like an oxea, but with a swollen region where the clades connect. One ray of the diactines is sometimes spined. Basal clades of triacts: 51-75-110 x 8-15-20 $\mu \mathrm{m}(\mathrm{n}=35)$, lateral clades of triacts: 57-128-200 x 5-13-20 $\mu \mathrm{m}(\mathrm{n}=32)$. Straight diacts 133-210-311 $\mu \mathrm{m}$ in total length, 9-13-22 $\mu \mathrm{m}$ wide at widest point excluding enlarged central $\operatorname{knob}(\mathrm{n}=9)$.

Trichodragmas: 67-75-88 x 7-12-18 $\mu \mathrm{m}(\mathrm{n}=13)$; width of individual raphides not measured.

Distribution and habitat. Rocky reef. Depth range 17-94 m. Known from Palos Verdes, Los Angeles County, California to Guerrero, Mexico. We found it to be common, but not abundant, on reefs below $20 \mathrm{~m}$ in Los Angeles and San Diego Counties. We did not find it North of Palos 
Verdes, but most search effort North of this region has been at less than $15 \mathrm{~m}$ depth, so records farther North are likely in deeper water.

Discussion. Trikentrion helium was described from Cedros Island, Baja California, Mexico (Dickinson 1945). It was later collected at various locations around San Diego, California (Luke 1998; Smith 1968), and these collections were used in the chemical analyses that characterized the structure of the carotenoid now known as trikentriorhodin (Aguilar-Martinez \& LiaaenJensen 1974). More recently, it was reported as common at reefs around the Palos Verdes Peninsula, Los Angeles, California (Claisse et al. 2018).

Trikentrion catalina was described from two sponges collected at Catalina Island, Southern California (Sim \& Bakus 1986). Five sponges from the Mexican tropical Pacific, from Nayarit and Guerrero, were later ascribed to this species as well (Gómez et al. 2002). The authors of both papers on T. catalina, however, appeared to have overlooked T. helium, as this species is extremely similar but was not mentioned. Van Soest et al. (2012) re-describe the holotypes of both species and verified that they were closely related, noting only two differences. First, the $T$. helium holotype contained diactinal polyactines and the $T$. catalina holotype did not. Second, growth form was subtly different: "undulating thin-bladed sheets together forming a bushy mass" in T. helium vs. a single stalked blade growing mostly in a single plane in $T$. catalina. The freshly collected samples described here have diactinal polyactines and would therefore be ascribed to $T$. helium, but the growth forms more closely match $T$. catalina. The fresh sample from the Palos Verdes peninsula was collected $30 \mathrm{~km}$ from the type location for $T$. catalina, and these locations are biogeographically similar. We therefore propose that T. catalina be considered a junior synonym of T. helium.

Trikentrion helium is distinctive and should usually be identifiable in the field based on gross morphology alone. The most similar known species is E. hyle; see discussion section above for that species for additional information. 


\section{Genus Cyamon (Gray, 1867)}

\section{Cyamon neon (de Laubenfels 1930)}

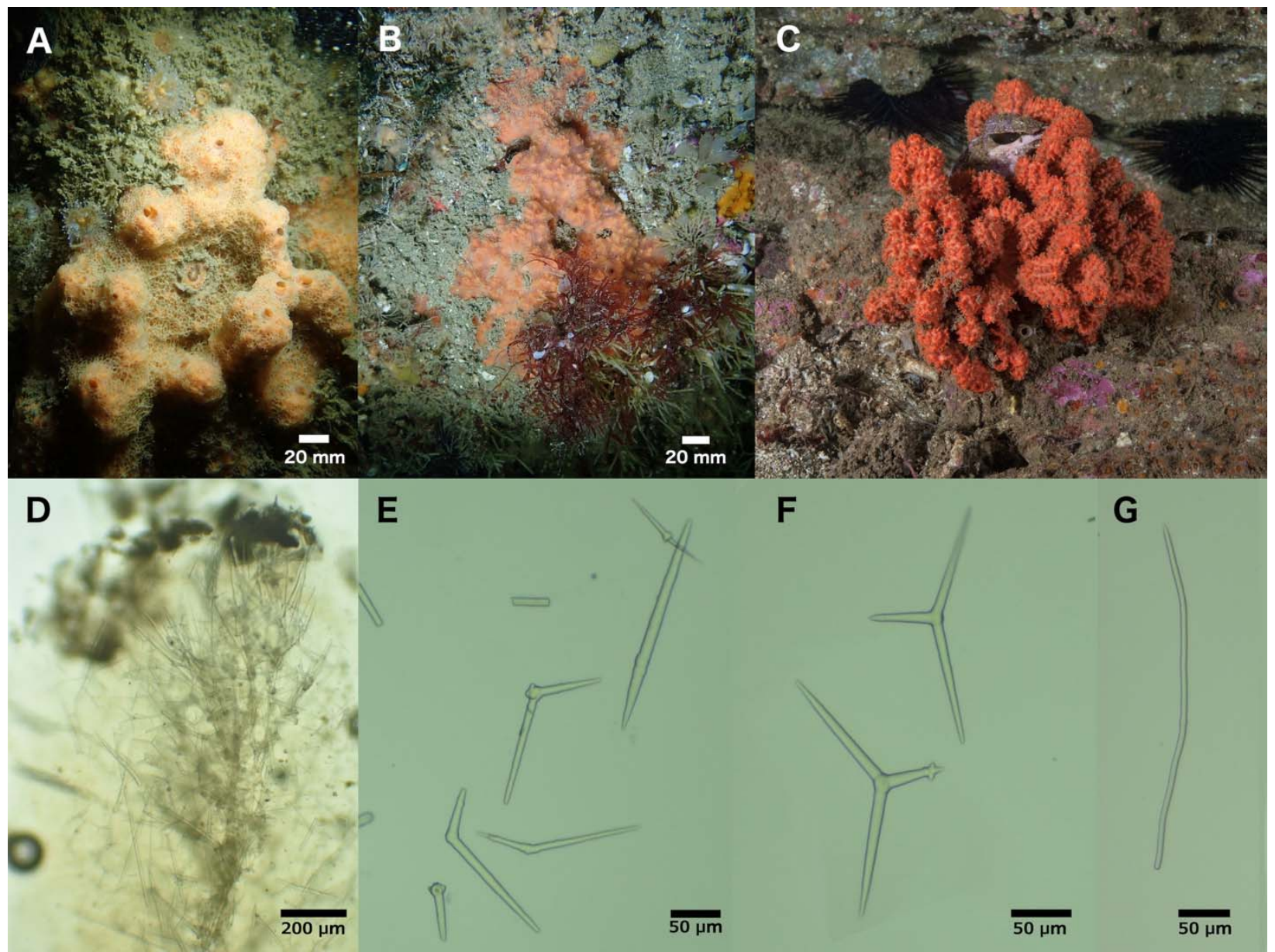

Figure 11. Cyamon neon. Field photos of A: TLT11 (TBD), B: TLT486 (TBD), and C: an uncollected bush-like sample, photographed by Mary Passage at Resort Point Reef, off the Palos Verdes Peninsula, at approximately $21 \mathrm{~m}$ depth. D: Skeletal structure of TLT233 (TBD) at the periphery. E: Variety of diactinal polyactines from TLT462 (TBD). F: Polyactines from TLT462 (TBD). G: Wavy centrylote strongyle/style from TLT 462 (TBD).

Cyamon neon (Lee et al. 2007a; Sim \& Bakus 1986; Smith 1968; van Soest et al. 2012)

\section{Material examined.}

Samples collected by TT: NHMLA 16556 / BULA-0546, Hawthorne Reef, Palos Verdes Peninsula, Los Angeles (33.74714, -118.42090), 18-24 m, 8/23/2019; TLT 3 (CASIZ TBD) and TLT 11 (CASIZ TBD), Elwood Reef, Santa Barbara (34.41775, -119.90150), 9-14 m, 4/17/2019; TLT 233 (CASIZ TBD), Arroyo Quemado Reef, Santa Barbara (34.46775, -120.11905), 7-11 m, 7/29/2019; TLT 462 (CASIZ TBD) and TLT 486 (CASIZ TBD), Parson's Landing, Catalina Island (33.47502, -118.55000), 8-17 m, 11/10/2019; Samples collected by others: NHMLA 
15920 / BULA-0229, Marineland, Palos Verdes, Los Angeles (33.75166667, -118.41665), depth not recorded, collected by Gustav Paulay.

Morphology. Thickly encrusting (1-2 cm) or with upright lobes up to $5 \mathrm{~cm}$ tall; larger sponges become a bushy mass. Internal columns of orange flesh end in hispid conules, making sponge surface extremely rugose. Covered in a whitish, partially transparent, porous dermal membrane; large pores (approx. $0.5 \mathrm{~mm}$ ) in this membrane create a spider-web-like aspect when sponge is alive and relaxed. Oscules occur singly or in pairs, primarily in elevated areas, each 1-2 mm in diameter. Orange in life; reacts to ethanol and turns very dark brown.

Skeleton. Thick (200-400 $\mu \mathrm{m}$ wide) columns of spongin, styles, and polyactines ascend towards the sponge surface, splitting into thinner columns towards the ectosome. Thinner $(<100 \mu \mathrm{m})$ columns of spongin cored with styles form sparser, plumoreticulated regions beneath conules, with fewer polyactines present. Centrylote strongyles are found in tangential bundles near the ectosome, but also scattered throughout.

Spicules. Short styles, long styles, wavy centrylote strongyles, polyactines (with 2-5 clades).

Short styles: curved or slightly bent near head end; 284-429-605 x 3-14-29 $\mu \mathrm{m}(\mathrm{n}=79)$.

Long styles: curved or slightly bent near head end; $865-1235-1479 \times 7-10-13 \mu \mathrm{m}(\mathrm{n}=14)$.

Wavy centrylote strongyles: thin with blunt ends (strongylote) or with one or both ends pointed (style/oxea); often but not always with a centrylote swelling; 177-302-482 x 2-4-8 $\mu \mathrm{m}(\mathrm{n}=27)$.

Diactinal polyactines: unspined, with irregular centrylote swelling; straight or bent at the centrylote swelling. 58-206-382 x 5-10-17 $\mu \mathrm{m}(\mathrm{n}=46)$.

Other polyactines: mostly three claded, but occasionally with 4 or 5 clades. Highly variable angles between clades; usually with one shorter (basal) clade; usually entirely unspined, but very small spines sometimes present, sometimes on all clades and sometimes limited to the basal clade. Basal clades 31-49-64 x 6-11-18 $\mu \mathrm{m}(\mathrm{n}=49)$; lateral clades 67-106-167 x 5-11-19 $\mu \mathrm{m}$ $(n=56)$.

Distribution and habitat. Known from Southern California to Cedros Island, Baja California, Mexico. Depth range 7-27 m (though Lee et al. (2007a) report that it is intertidal, we know of no published reports from the intertidal, nor did we find any intertidally). We found it to be common but patchy in Southern California, locally abundant in some places but absent from others. In total, it was found at 11 of 52 natural rocky reefs surveyed in Southern California, without any apparent geographic pattern in abundance. It was not found on any human structures (wrecks, pilings, floating docks, or oil rigs).

Discussion. Cyamon neon was described from three samples collected near San Pedro in Southern California (de Laubenfels 1932). de Laubenfels noted that the sponge was dark brown, and that the ectosome was full of dark brown granules, which we can now report are formed when the sponge reacts to ethanol. 
A very similar species, Cyamon argon (Dickinson 1945), was later described from a single sample collected at Cedros Island, Baja California, Mexico. The holotypes were compared by Smith (1968), who proposed that they were synonymous, and by van Soest et al. (2012), who noted their similarity but retained both species. The differences originally noted in the C. argon description were revised by later authors, but three differences were noted by von Soest et al., as follows. First, the $C$. neon holotype is thickly encrusting while the $C$. argon holotype is more upright and bush-like. However, we found $C$. neon with vertical growth, and it was previously reported that $C$. neon in deeper waters are more erect and branching, with heights up to $10 \mathrm{~cm}$ (Smith 1968). As shown in figure 11C, Cyamon from the type locality for $C$. neon grow to be very bush-like at depths below $20 \mathrm{~m}$. Second, some spicules were notably thicker in the $C$. argon holotype than the $C$. neon holotype. Though this difference is slight, it is true that all of the samples we have examined have thinner spicules like the $C$. neon holotype. However, Smith (1968) examined both the holotype and paratype of $C$. neon: while his measures of the $C$. neon holotype matched those of others, he found the paratype to have styles as thick as $C$. argon. Other samples collected around La Jolla, San Diego also had spicules as thick as $C$. argon. Finally, the basal clades of the polyactines are more prominently spined in the $C$. argon holotype than the $C$. neon holotype. Though most polyactines are unspined in our samples, we found a few that had prominently spined basal clades (fig. 11), and this was also reported by Smith (1968). Considering a larger sample of $C$. neon material therefore makes the differences between the $C$. argon and $C$. neon holotypes appear to be intraspecific variation. There are also no notable habitat differences, as the $C$. argon holotype was collected on shallow $(18-27 \mathrm{~m})$ rock reef among giant kelp, which is the same habitat where all the $C$. neon samples are found. We therefore propose that $C$. argon be considered a junior synonym of $C$. neon.

\section{Cyamon koltuni (Sim \& Bakus 1986)}

Material examined. None.

Morphology. Thinly encrusting, up to $1 \mathrm{~mm}$ thick. Bright orange and hispid.

Skeleton. Basal mass of polyactines with emergent styles.

Spicules. Long thin styles, short thin styles, short thick styles, and polyactines. For dimensions see (2012)

Distribution and habitat. Known from two samples, one from Bird Rock, Catalina Island, California, and the other from the Islas Marietas, Nayarit, Mexico.

Discussion. This species was not examined but is included here for completeness. It is easily distinguished from other California species by possession of polyactine spicules with bulbous spined tips. It is unlikely to be distinguishable in the field due to the many thinly encrusting red and orange sponges known in California. 
bioRxiv preprint doi: https://doi.org/10.1101/2022.03.02.482672; this version posted March 4, 2022. The copyright holder for this preprint (which was not certified by peer review) is the author/funder, who has granted bioRxiv a license to display the preprint in perpetuity. It is made available under aCC-BY-NC-ND 4.0 International license.

\section{Family Stelligeridae (Lendenfeld 1898)}

\section{Genus Halicnemia (Bowerbank 1864)}

\section{Halicnemia litoria sp. nov.}
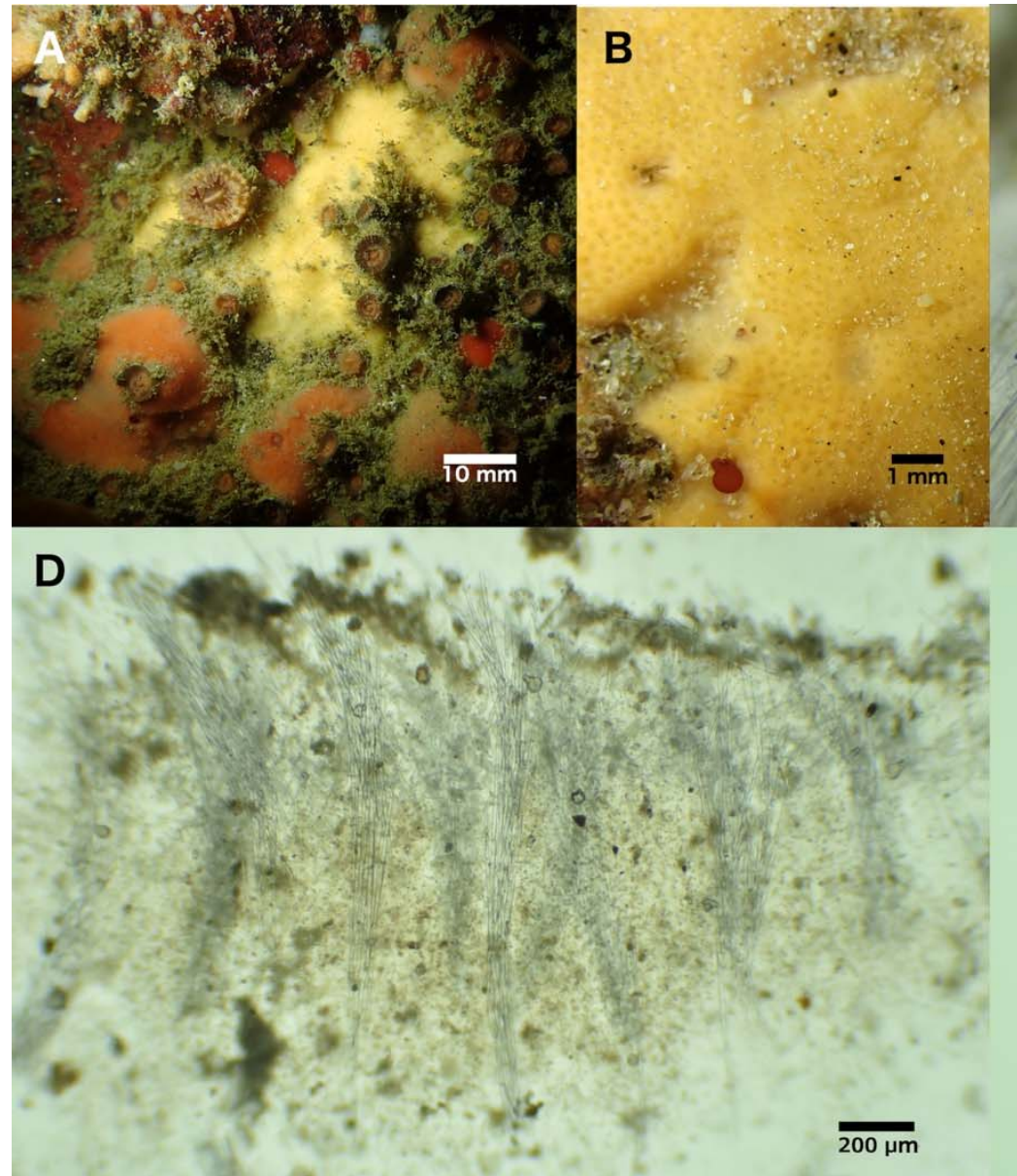

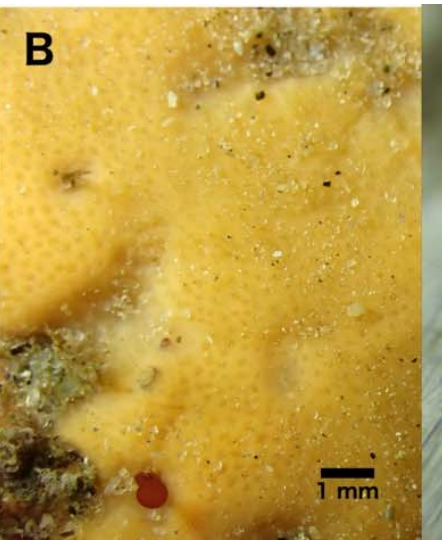

$E$
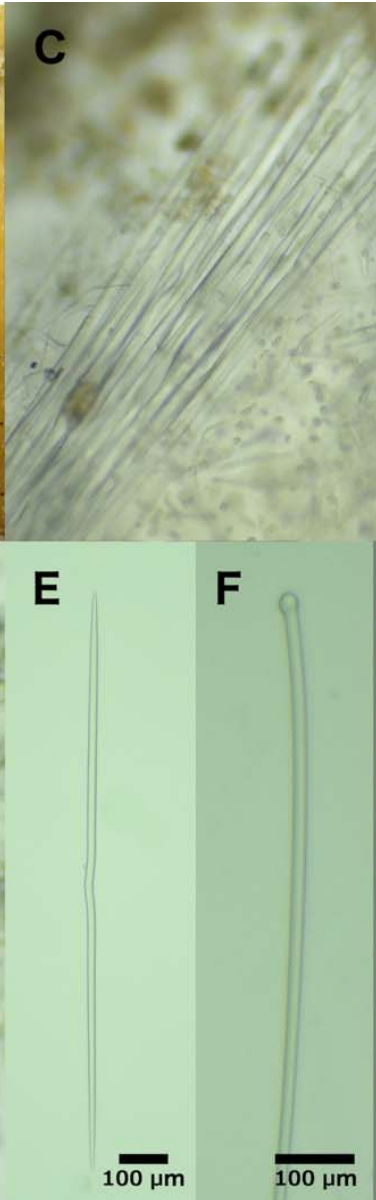

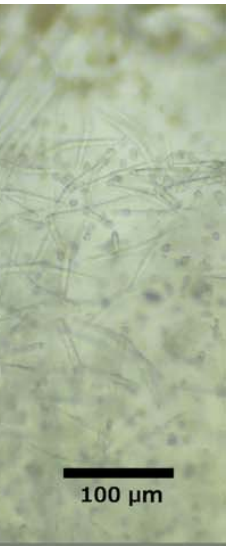

G

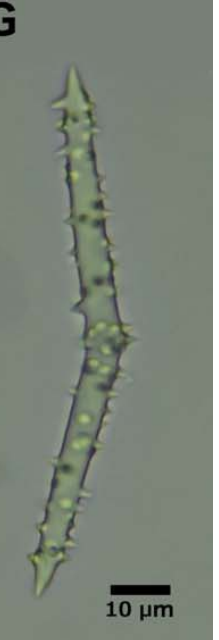

Figure 12. Halicnemia litoria. A: Field photo of holotype (TLT479 TBD). B: Field photo of paratype (TLT1197 TBD). C: Skeletal structure of holotype. D: Skeletal structure of patatype (TLT169 TBD). E-G: Spicules from holotype. E: Oxea with central kink, F: Head of tylostyle, G: Acanthoxea.

Higginsia ?higginissima (Ristau 1977)

Higginsia sp. Bakus and Abbot 1980 (Bakus \& Abbott 1980; Klontz 1989)

"Higginsia sp. Klontz, 1989", in part (Lee et al. 2007a)

Material examined. Holotype: TLT479 (CASIZ TBD), Otter Cove, Monterey, (36.62920, 121.92031), depth 5-12 m, 11/24/2019, collected by TT; TLT169 (CASIZ TBD), Isla Vista Reef, Santa Barbara, (34.40278, -119.85755), depth 5-12 m, 8/1/2019, collected by TT; TLT201 (CASIZ TBD), Coal Oil Point, Santa Barbara, (34.40450, - 119.87890), on loose stone in a tidepool, 7/6/2019, collected by TT; TLT1179, Cannery Row, Monterey, (36.61798, -121.8978), 
depth 9-16 m, 9/21/2021, collected by TT; CASIZ 66860, SE Farallon Island, "mussel bed study site and Jewel Cave", intertidal, 12/6/1975, collected by "Chaffee, Bowman, and Heinonen" (Farallon Research Group); CASIZ 108558, Santa Rosa Island, "1.2 mi E of Fort Point", 12-14 m depth, 8/29/1985, collected by Sarah Ward Klontz; CASIZ 178096, Pigeon Point, San Mateo County, intertidal , 7/17/2004, collected by "Moss Landing Marine Lab"; CASIZ 180207, Channel Islands Harbor, Ventura, 0-3 m depth, 7/25/2006, collected by "Moss Landing Marine Lab".

Etymology. Named for its habitat (the littoral), which is unusual for the genus.

Morphology. Thinly encrusting. Holotype was approximately 4 x $4 \mathrm{~cm}$ in life and $2 \mathrm{~mm}$ thick; other samples 2-4 mm thick. The four freshly collected samples, including the holotype, were yellow when alive; where noted in museum records, other samples were yellow, yellow-green, yellow-orange, or orange at collection; preserved samples are beige to pale yellow. Several samples, including the holotype, were notably slimy at collection; slime was not noted for the other samples but may have been present. Hispidity is apparent in field photos but difficult to see with the naked eye.

Skeleton. Bundles of megascleres rise vertically from the substrate, fanning out slightly as they approach and pierce the surface to create hispidity. Acanthoxeas are strewn throughout the sponge, but are most abundant near the surface. Small irregular particles that appear to be sand grains are also abundantly incorporated throughout the sponge. Surface is often very silty.

Spicules. Tylostyles, oxeas, and acanthoxeas; sometimes centrylote microxeas.

Tylostyles: bearing a well-formed round head or subterminal bulge. Width slowly tapering to points; pooled samples 615-1268-1923 x 7-17-28 $\mu \mathrm{m}(\mathrm{n}=68$; average length in each sample varies from 951 to $1671 \mu \mathrm{m})$.

Oxeas: straight but usually bearing a distinctive kink near the center. Centrylote swelling absent on most spicules, but weakly present on or near the kink in a few; holotype 536-839-993 x 6-10$13 \mu \mathrm{m}(\mathrm{n}=36)$; pooled samples 233-810-1070 x 1-10-18 $\mu \mathrm{m}(\mathrm{n}=189$; average length in each sample varies from 603 to $924 \mu \mathrm{m})$.

Acanthoxeas: generally bent in the center (centrangulate) but some gently curved. Some have a centrylote bulge on or near bend but this is often absent. Spines vary in length and density, with most samples having both longer and shorter spined spicules; sample CASIZ 66860 is atypical in that its spicules are very densely spined. Holotype: 66-87-109 x 4-6-9 $(n=51)$; pooled samples: 44-73-132 x 3-5-11 $\mu \mathrm{m}(\mathrm{n}=302$; average length in each sample varies from 55 to $87 \mu \mathrm{m})$.

Centrylote microxeas: centrangulate like acanthoxeas, and similar in length, but thinner, with centrylote bulge more common. Usually entirely unspined. Found in only 4 of 8 samples, and much less common than acanthoxeas even when present; some previous workers have noted that these are likely immature acanthoxeas (Morrow et al. 2019). Not seen in holotype. Pooled samples: 45-60-78 x 1-3-5 $\mu \mathrm{m}(\mathrm{n}=17)$. 
Distribution and habitat. Uncommon from Bodega Head in Northern California to Oxnard Harbor in Southern California, and from the intertidal to $16 \mathrm{~m}$ in depth. Of the four samples we found, three were on shallow $(<16 \mathrm{~m})$ rocky ridges under kelp canopy, in one case partially buried by sand; the fourth was in a tidal pool.

Discussion. Though undescribed, this sponge has been noted by several previous authors (see below), who often noted that it was similar to the description of Higginsia higginissima (Dickinson 1945) from the Sea of Cortez. This claim is difficult to assess based on Dickenson's original description, which was very limited. Thankfully, fresh H. higginissima were described in much more detail by Gomez et al. (2002). As H. higginissima is branching, treelike, and has much smaller styles that are not tylote, it is clearly distinct from $H$. litoria; see also (Hofknecht 1978). No other Higginsia are known from the Eastern Pacific, and encrusting species are now placed in the genus Halicnemia rather than Higginsia.

We are aware of three previous reports of Halicnemia in the Eastern Pacific. The otherwise Atlantic $H$. patera was reported as occurring in British Columbia, albeit with no supporting data published (Austin 1985). Halicnemia patera differs from H. litoria by being disk-shaped, having longer tylostyles with multiple tyles, longer oxeas with centrylote tyles, and longer acanthostyles. As noted in the H. monteriensis section below, the British Columbia sponges might be members of that species.

A more similar species is $H$. diazae (Desqeyroux-Faundez \& van Soest 1997), described from the Galapagos and reported as occurring in the Mexican Tropical Pacific (Carballo et al. 2019). Halicnemia diazae is also the only previous species of Halicnemia described from the intertidal. These species have considerable differences as well, however, with $H$. diazae having echinating rhabdostyles (absent in H. litoria), longer centrylote oxeas without a central kink, longer tylostyles, and thicker encrustations. The final species known from the Pacific is the Chilean $H$. papillosa, which has small styles (absent in H. litoria) and longer acanthoxeas (Desqeyroux-Faundez \& van Soest 1997). The remaining species are known only from the Atlantic and Mediterranean, mostly from deep water, and all are distinguished from $H$. litoria by the presence of additional spicules and/or spicule dimensions. Most have longer acanthoxeas than $H$. litoria; an exception is $H$. geniculata from the Mediterranean; this species is a thin yellow encrustation with similar acanthoxeas to $H$. litoria, but has much thinner tylostyles and oxeas, and the oxeas are sinuous and lack the central kink (Bertolino et al. 2013).

This central kink has previously been reported only by Morrow et al (2019), who noted that a minority of $H$. patera oxeas lack centrylote swelling but have a central kink; in the same paper, images of $H$. gallica oxeas show that some are both kinked and centrylote. These two species differ from $H$. litoria in other aspects of spicular architecture and spicular morphology. It is interesting that the central kink is also shared by $H$. monteriensis, described below, despite considerable differences between that deep-water species and this shallow one. Future molecular work is needed to determine if the kinked oxea is convergent or homologous among these taxa.

Halicnemia litoria is easily distinguished from the other California Halicnemia described below. It is very different from $H$. weltoni in both spicular complement and skeletal architecture. It is more similar to $H$. monteriensis in spicule complement, though the distributions of spicule sizes for these species are non-overlapping for all spicule types, and the skeletal morphology is very different.

This species has been mentioned by several previous authors, who reported rare specimens from the intertidal in Northern and Central California (Bakus \& Abbott 1980; Klontz 
1989; Ristau 1977). Consistent with overall rarity, it was not found in the extensive intertidal collections made by de Laubenfels in the 1920s (de Laubenfels 1932) nor in the Southern California Bight surveys conducted between 1976-1978 (Bakus \& Green 1987). Two sponges similar to $H$. litoria were found in a Southern California survey of water deeper than $50 \mathrm{~m}$, and reported as "?Desmoxyidae sp. A" (Green \& Bakus 1994). These samples were reported as having additional small tylostyles and larger acanthoxeas than $H$. litoria, but are otherwise a good match, so it is possible $H$. litoria also occurs in deep water.

Additional data could result in $H$. litoria being spilt into two or more species. The lengths and widths of all spicule types varied among samples, with averages falling roughly into two groups. The four samples from Northern and Central California grouped with a sample from Santa Rosa Island: these four samples have longer and thicker spicules than the three samples from mainland Southern California. These Southern, smaller-spiculed samples occur in waters with higher average surface temperatures and are separated from the others by the geographic barrier at Point Conception; the Southern population on Santa Rosa Island matches the Northern populations in morphology, but this outer island is bathed in colder water from the California current. This morphological separation is subtle, however, with some samples showing intermediate values for some spicule types, and is not supported by the genetic data. As explained in the phylogenetic results, samples show much more apparent genetic variation that seen for other species, but this does not associate with the morphological variation, as the sample from Central California groups with one of two samples from Southern California.

This species is difficult to identify in the field as it is usually quite small and lacking in surface features. 


\section{Halicnemia monteriensis sp. nov.}

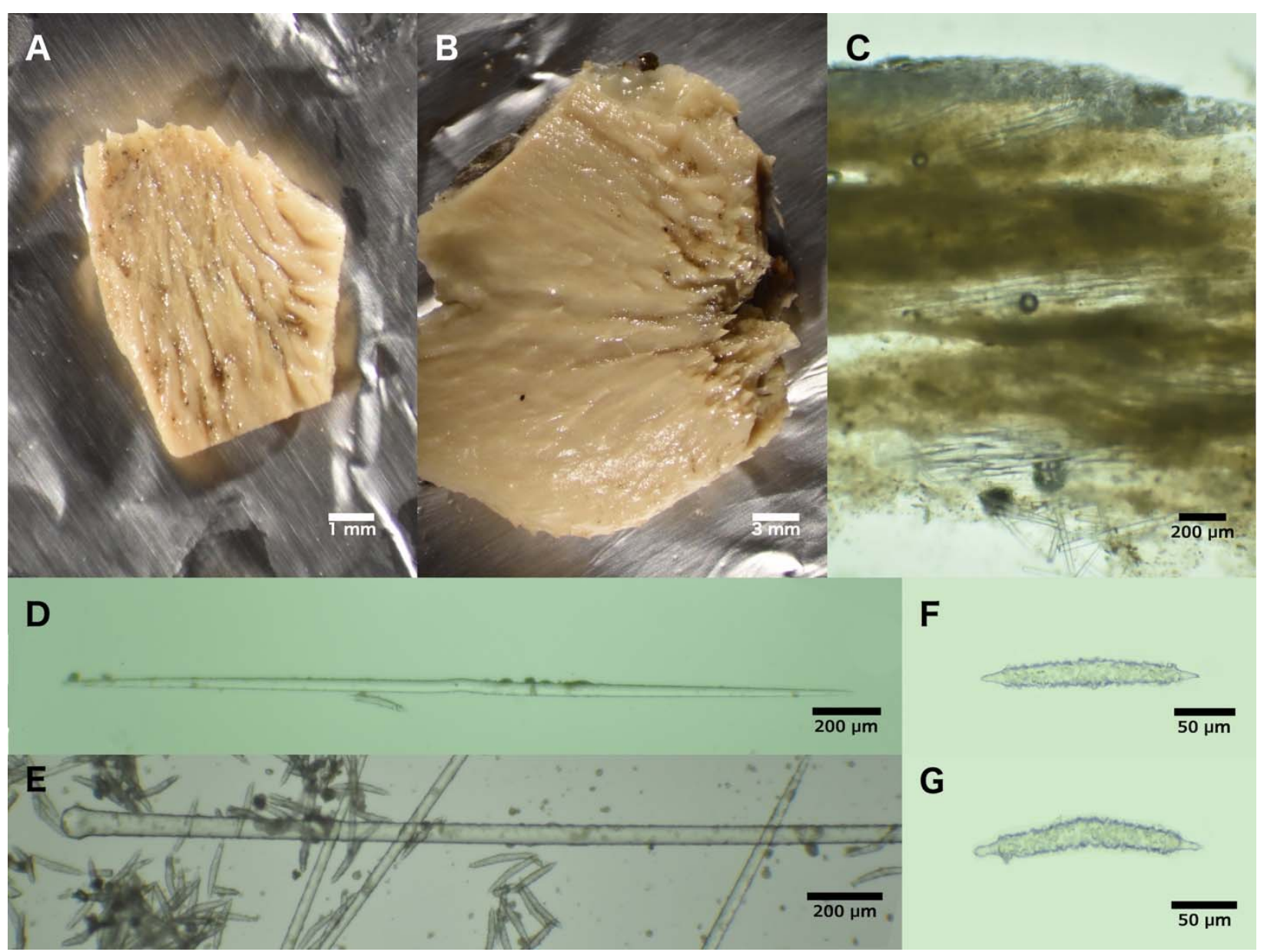

Figure 13. Halicnemia monteriensis. A: Holotype, CASIZ 165841, post-preservation. Paratype, CASIZ 165844, post-preservation. C: Tangential section of holotype showing spicule bundles and crust of acanthoxeas. D: Kinked oxea from CASIZ 165844. E: Head of tylostyle from CASIZ 165838. F-G: Acanthoxeas from CASIZ 165844.

"Higginsia sp. Klontz, 1989" in part (Lee et al. 2007)

Material examined. Holotype: CASIZ 165841; paratypes CASIZ 165838, CASIZ 165844; all samples collected at the "concrete block area", Monterey Bay Canyon, Monterey, 378-379 m, 6/3/1994. Spicule measurements from CASIZ 165838 and 165844.

Etymology. Named for the collection location, Monterey Canyon.

Morphology. Samples form asymmetrical, sloping encrustations that rise into low mounds, 1-2 $\mathrm{mm}$ thick at one end, rising to 5-7 mm thick at the other. Prominent conules lie flat along the sponge surface and point towards thick end; sponge terminates in a cluster of conules forming a tuft. Color alive unknown; white/tan in ethanol. Holotype noted as exuding slime by collectors. 
Skeleton. Acanthoxeas form a thick surface crust and a thinner crust along substrate; no acanothoxeas seen in between. Heads of tylostyles seen embedded along substrate, pointing up, but no complete tylostyles recovered in sections. Oxeas tightly bundled into cables 8-20 spicules thick which run at various angles, some parallel to surface, others slightly angled up; some terminate in surface conules.

Spicules. Tylostyles, oxeas, and acanthoxeas.

Tylostyles: bearing well-formed round heads, width slowly tapering to points. Uncommon, and with points usually broken, so lengths are an underestimate; 3672-4037-4223 x 55-60-63 $\mu \mathrm{m}$ $(n=3)$.

Oxeas: often but not always with distinctive kink near the center. Kink is less distinct in $H$. monteriensis than in H. litoria, and many oxeas are completely straight; 1647-2177-2559 x 2632-37 $\mu \mathrm{m}(\mathrm{n}=30$; average length of each sample separately: 2062, $2212 \mu \mathrm{m})$.

Acanthoxeas: a minority are bent in the center (centrangulate) but most are gently curved or straight. Very heavily spined except near tips; 118-167-202 x 14-19-23 $\mu \mathrm{m}(\mathrm{n}=58$; average length of each sample separately: 164, 173).

Distribution and habitat. Known only from a single collection, at the "concrete block area" in Monterey Canyon, Central California, 378-379 m depth.

Discussion. The most distinctive thing about this sponge is its skeletal arrangement and overall morphology. The tight bundles of oxeas arise from the substrate at an acute angle, travel in various directions, and some terminate in conules and tufts. This gives the sponge a leaning aspect and invokes an up-do hairstyle. This overall morphology and skeleton is very similar to the description of $H$. patera in (Ackers et al. 2007). However, a later revision indicates that this description instead pertains to $H$. gallica, which had been lumped with $H$. patera but was later resurrected (Morrow et al. 2019). A second species has this same morphology and skeleton: $H$. wagini (Morozov et al. 2018). It therefore seems likely that $H$. gallica, $H$. wagini, and $H$. monteriensis inherited this morphology from a common ancestor. DNA data is only available for $H$. gallica thus far, so this hypothesis remains to be tested.

Halicnemia monteriensis is distinguished from all previous Halicnemia by the dimensions of its spicules: all spicules are the longest yet reported for their type, and are much thicker than previous descriptions. The acanothoxeas of $H$. monteriensis are approached in length by $H$. patera and $H$. wagini, but the maximum recorded widths of acanthoxeas for all previous species vary from 2-12 $\mu \mathrm{m}$, while $H$. monteriensis averages $19 \mu \mathrm{m}$ with a maximum of $23 \mu \mathrm{m}$. Likewise, oxeas are longer and much thicker in $H$. monteriensis (maximum reported thickness 5 $20 \mu \mathrm{m}$ for all previously reported species, vs. an average $32 \mu \mathrm{m}$ and maximum of $37 \mu \mathrm{m}$ in $H$. monteriensis); the same pattern is true for tylostyles.

Halicnemia monteriensis is easily distinguished from the California species described here. Welton Lee identified these samples as "Higginsia sp. Klontz 1989", together with some of the $H$. litoria described above, but these deep-water samples are quite distinct from the shallow water $H$. litoria. All three spicule types are much longer and thicker in $H$. monteriensis than $H$. litoria (size distributions are non-overlapping for both length and width for each spicule type). 
bioRxiv preprint doi: https://doi.org/10.1101/2022.03.02.482672; this version posted March 4, 2022. The copyright holder for this preprint (which was not certified by peer review) is the author/funder, who has granted bioRxiv a license to display the preprint in perpetuity. It is made available under aCC-BY-NC-ND 4.0 International license.

Gross morphology differs, with $H$. monteriensis forming the sloping mounds described above and $H$. litoria forming thin encrustations with no conules. Spicular architecture is different as well, with bundles of megascleres rising at right angles to the substrate in $H$. litoria and running nearly horizontally in $H$. monteriensis. The acanthoxeas of $H$. monteriensis are less centrangulate, have larger spines, and are more densely spined than other species described here -- except for one sample of $H$. litoria (CASIZ 66860) which shows more densely spined acanthoxeas reminiscent of $H$. monteriensis.

Most previously described species of Halicnemia have oxeas with one or more centrylote swellings. It is interesting that $H$. monteriensis and $H$. litoria share a central kink instead of the central swelling, despite otherwise seeming very different. As discussed above, this feature is apparently shared with two other Halicnemia (Morrow et al. 2019) but only one of these $(H$. gallica) shares the sloping morphology of $H$. monteriensis.

There is a previous report of H. patera in British Columbia (Austin 1985). The report is hard to assess, as it is simply a species list with no descriptive data, but it is possible that the British Columbia samples are $H$. monteriensis due to the similarities with the morphological description previously attributed to $H$. patera (Ackers et al. 2007).

\section{Halicnemia weltoni sp. nov.}

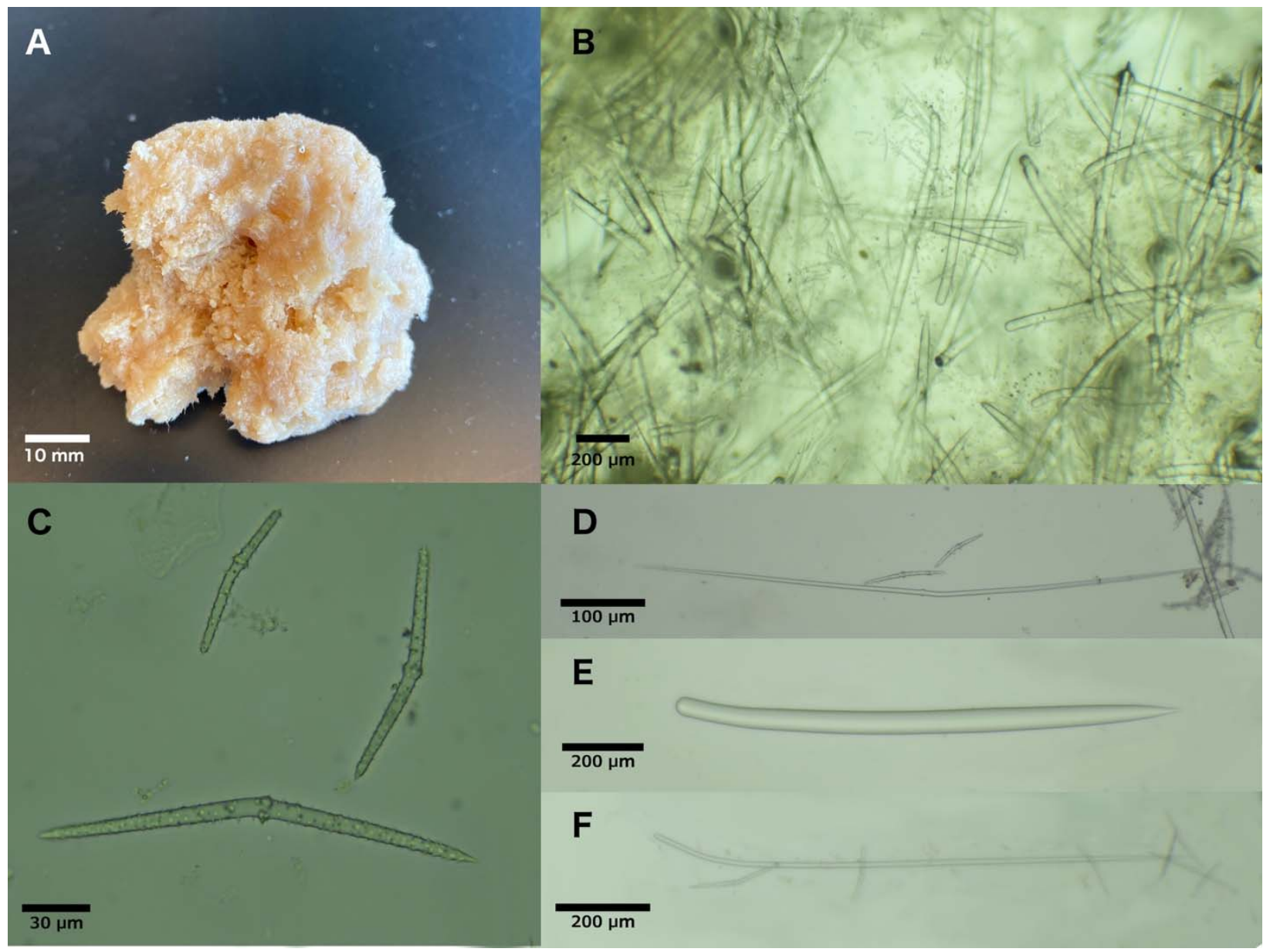


Figure 14. Halicnemia weltoni. A: Holotype, CASIZ 108411, post-preservation. B: Tangential section of CASIZ 184380. C: Acanthoxeas from holotype. D: Centrylote oxea from paratype. E: Thick style from holotype. F: Thin style from holotype.

Higginsia sp. 1 (Lee et al. 2007a)

Material examined. Holotype: CASIZ 108411, Cordell Bank, Marin County, $82 \mathrm{~m}$ depth, collected Sept. 1940 by "Swift, Smith, Hannah". CASIZ 184380, Cordell Bank, Marin County (38.023, -123.4263), 55-61 m depth, collected 10/9/10, collectors not recorded.

Etymology. Named for Welton Lee, formerly of the California Academy of Sciences.

Morphology. The holotype is a roundish mass, about $50 \times 30 \mathrm{~mm}$, which could be described as thickly encrusting or massive. Sample CASIZ 184380 is flatter, 20 x 10 x 5 mm. Both are hispid, rugose and irregular, somewhat compressible; preserved color is white, live color is unknown.

Skeleton. A chaotic, halichondriid reticulation of thick styles without visible spongin. Oxeas and thin styles are loosely organized into bundles, some of which pierce the surface of the sponge to create hispidity. Acanthoxeas form a dense surface crust but are also common throughout the sponge. Small irregular particles that appear to be sand grains are also incorporated throughout the sponge.

Spicules. Thick styles, thin styles, long oxeas, and acanthoxeas.

Thick styles: not tylote. Could be characterized as rhabdostyles, as they often have a sharp bend near head end; 650-898-1221 x 27-36-46 $\mu \mathrm{m}(\mathrm{n}=38$; average length of each sample separately: $887,1081 \mu \mathrm{m})$.

Thin styles: sometimes with weak subterminal swelling but otherwise non-tylote. Straighter and less common than thick styles; 746-1186-1957 x 5-16-27 $\mu \mathrm{m}(\mathrm{n}=12$; average length of each sample separately: 1080, $1262 \mu \mathrm{m}$ ).

Long oxeas: often bent near center (centrangulate), but many are smoothly curved or straight. Usually, but not always, with weak centrylote swelling; 607-1041-2845 x 5-11-26 $\mu \mathrm{m}$ (n=34; average length of each sample separately: $887,1177 \mu \mathrm{m})$.

Acanthoxeas: usually centrangulate, sometimes with weak centrylote swelling. Small spines cover the entire surface; 49-133-221 x 3-6-9 $\mu \mathrm{m}(\mathrm{n}=51$; average length of each sample separately: $121,148 \mu \mathrm{m})$.

Distribution and habitat. Known only from a single collection from Cordell Bank National Marine Sanctuary, Marin, California, 55-82 m depth.

\section{Discussion.}

The differentiation between Halicnemia and Higginsia remains incompletely clear. Morrow (2019) states that Halicnemia have tylostyles while Higginsia have only styles. Halicnemia 
weltoni has only styles, but the thinner ones are sometimes subtylote and could be derived from tylostyles. Halicnemia are described as encrusting or disk-shaped while Higginsia are "erect, lamellate, massive, vasiform or lobate" (Hooper 2002a). While H. weltoni could be considered massive, it is similar to other massively encrusting Halicnemia and differs from most Higginsia, which are stalked and branching or upright and digitate. It is perhaps most similar to Halicnemia diazae, which has rhabdostyles and a skeleton described as "pluomse-dendritic" (DesqeyrouxFaundez \& van Soest 1997). We consider Halicnemia to be a better fit, though it seems likely that future revision is needed to clearly define and separate these two genera.

The lack of tylostyles distinguishes this species from all described Halicnemia except $H$. arcuata, which has much shorter oxeas and acanthoxeas. Rhabdostyles are present in only two other Halicnemia, and in both cases they are much shorter and thinner (H. diazae 280-770 x 10$23 \mu \mathrm{m} ; \mathrm{H}$. geniculata $147-705$ × 2-4 $\mu \mathrm{m}$; vs. H. weltoni $650-1221 \times 27-46 \mu \mathrm{m})$.

This new species can also be differentiated from named Higginsia. The only other Eastern Pacific Higginsia, H. higginissima, is branching and treelike with much smaller spicules (Gómez et al. 2002). Having thick, plain styles as the principal skeletal component also differentiates this species from most Higginsia described world-wide. Many Higginsia have oxeas only, and those with styles and oxeas usually have oxeas as the principal skeletal component and thin styles as peripheral components (e.g. H. higgini, H. massalis). The only species where styles comprise the primary skeleton (or where styles are present and descriptions of skeletal architecture are limited) have much smaller styles (H. robusta [styles $740 \mu \mathrm{m}$ ], $H$. thielei [styles 600-700 $\mu \mathrm{m}$ ], H. pulcherrima [styles 420-520 $\mu \mathrm{m}$ ]).

These samples were previously investigated by Lee et al. (2007a), who recognized them as distinct from anything else known from the region and referred to them as "Higginsia sp. 1 [of Lee]". In the same publication, another sponge from the same location was referred to as "Higginsia sp. 2 [of Lee]", and said to be perhaps conspecific with Higginsia sp. 1 but contaminated with foreign spicules. We investigated sample CASIZ 108398, the only sample known to be identified as Higginsia sp. 2 by Welton Lee, and found it to contained no acanthoxeas and seemed to be of a different order. Finally, it should be noted that CASIZ 184380 also contains fragments from the species Forcepia macrostylosa.

\section{Dichotomous Key to California Axinellida}

1A. Contains polyactines ( 3 to 5 pointed spicules) ... 2

1B. No polyactines ... 4

2A. Polyactinces with bulbous tips: Cyamon koltuni (Sim \& Bakus 1986)

2B. Polyactines without bulbous tips ... 3

3A. Sponge with prominent laminate blades; polyactines with large spines on shortest clade: Trikentrion helium (Dickenson 1945)

3B. Sponge a thick encrustation or bushy mass; polyactines unspined or with small spines: Cyamon neon (de Laubenfels 1930)

4A. Contains acanthoxeas ... 5

4B. No acanthoxeas ... 7 
5A. Acanthoxeas average more than $10 \mu \mathrm{m}$ thick, long oxeas over $20 \mu \mathrm{m}$ thick: Halicnemia monteriensis sp. nov.

5B. Acanthoxeas average less than $10 \mu \mathrm{m}$ thick, long oxeas less than $20 \mu \mathrm{m}$ thick ... 6

6A. Acanthoxeas average 120 - $150 \mu \mathrm{m}$ long, long oxeas without central kink: Halicnemia weltoni sp. nov.

6B. Acanthoxeas average 50 - $90 \mu \mathrm{m}$ long, most long oxeas with central kink: Halicnemia litoria sp. nov

7A. Contains acanthostyles ... 8

7B. No acanthostyles ... 11

8A. Sponge is green alive and when preserved, acanthostyles are subtylote with bend near head: Aulospongus viridans sp. nov.

8B. Sponge red, orange, or yellow alive; white to beige in ethanol ... 9

9A. Many acanthostyles with severe (90 degree or more) bend near head, acanthostyles are subtylote, sponge is fan shaped: Raspailia (Raspaxilla) hymani (Dickenson 1945)

9B. Acanthostyles straight or with slight bend or curve, sponge not fan shaped ... 10

10A. Sponge comprised of bushy fronds or low mounds that crumble apart, acanthostyles average over $185 \mu \mathrm{m}$ long: Endectyon (Endectyon) hyle (de Laubenfels 1930)

10B. Sponge encrusting, acanthostyles average less than $185 \mu \mathrm{m}$ long: Endectyon hispitumula sp. nov.

11A. Contains only styles or with occasional rare oxeas ... 12

11B. Oxeas common, styles common or uncommon; oxeas \& styles of similar sizes ... 13

12A. Multiple size categories of styles; shortest category is sharply bent near center: Eurypon curvoclavus sp. nov.

12B. One size category of styles, not sharply bent: Endectyon hispitumula sp. nov.

13A. Oxeas \& styles both common, average lengths between 250 and $400 \mu \mathrm{m}$; sponge surface smooth: Dragmacidon mexicanum (de Laubenfels 1935)

13B. Oxeas more common than styles, average lengths between 800 and $1200 \mu \mathrm{m}$; sponge covered in tufts: Phycopsis piloerecta sp. nov.

\section{Conclusions}

Biological diversity provides an endless supply of discovery and inspiration. In the past, Axiniellid sponges in California have been used to make advances in natural products chemistry (Aguilar-Martinez \& Liaaen-Jensen 1974) and understanding archaeal symbiosis (Preston et al. 1996). The work reported here helps to delineate and organize the diversity in this order, creating a stable foundation for building additional discoveries. 
Reconciling the taxonomy of the species described here with their molecular phylogeny remains a daunting task. Our hope is that regional revisions like this one, which include both DNA and morphological data, provide insights that allow the community to work towards a global revision.

\section{Acknowledgements}

We are grateful for the help and support of many people in UCSB's Marine Science Institute and Diving \& Boating Program, especially Robert Miller, Clint Nelson, Christoph Pierre, and Christian Orsini. NOAA provided R/V Tegula small boat support for diving operations, and Steve Lonhat (NOAA) and Shannon Myers (UCSC) were instrumental in facilitating collections in Central California. The Natural History Museum of Los Angeles' DISCO program facilitated collections in Los Angeles County. Curators Christina Piotrowski and Kathy Omura graciously provided access to their collections at the California Academy of Sciences and the Natural History Museum of Los Angeles, respectively.

\section{Funding Declaration}

Financial support was provided by UCSB and by the National Aeronautics and Space Administration Biodiversity and Ecological Forecasting Program (Grant NNX14AR62A); the Bureau of Ocean Energy Management Environmental Studies Program (BOEM Agreement MC15AC00006); the National Oceanic and Atmospheric Administration in support of the Santa Barbara Channel Marine Biodiversity Observation Network; and the U.S. National Science Foundation in support of the Santa Barbara Coastal Long Term Ecological Research program under Awards OCE-9982105, OCE-0620276, OCE-1232779, OCE-1831937. The funders had no role in study design, data collection and analysis, decision to publish, or preparation of the manuscript.

\section{Works Cited}

Ackers, R.G., Moss, D., Picton, B.E., Stone, S.M.K. \& Morrow, C.C. (2007) Sponges of the British Isles: A color guide and working document. Marine Conservation Society.

Aguilar-Camacho, J.M. \& Carballo, J.L. (2013) Raspailiidae (Porifera: Demospongiae: Axinellida) from the Mexican Pacific Ocean with the description of seven new species. Journal of Natural History 47, 25-28.

Aguilar-Martinez, M. \& Liaaen-Jensen, S. (1974) Animal Carotenoids. 9*. Trikentriorhodin. Acta Chemica Scandinavica 28, 1247-1248.

Alvarez, B. \& Hooper, J.N.A. (2002) Family Axinellidae Carter, 1875. In: J. N. A. Hooper and R. W. M. van Soest (Eds), Systema Porifera: A Guide to the Classification of Sponges. Springer, Boston, pp. 742-747.

Austin, W.C. (1985) An Annotated Checklist of Marine Invertebrates in the Cold Temperate Northeast Pacific. Volume 1. Khoytan Marine Laboratory, Cowichan Bay, B.C. 
Austin, W.C., Ott, B.S., Reiswig, H.M., Romagosa, P. \& McDaniel, N.G. (2013) Two new species in the family Axinellidae (Porifera, Demospongiae) from British Columbia and adjacent waters. ZooKeys 338, 11-28.

Bakus, G.J. \& Abbott, D.P. (1980) Porifera: The sponges. In: R. H. Morris and E. C. Haderlie (Eds), Intertidal invertebrates of California. Stanford University Press, Redwood City, pp. 21-39.

Bakus, G.J. \& Green, K.D. (1987) The distribution of marine sponges collected from the 19761978 Bureau of Land Management Southern California Bight program. Bulletin of the Southern California Academy of Sciences 86, 57-88.

Belinky, F., Szitenberg, A., Goldfarb, I., Feldstein, T., Worheide, G., Ilan, M. \& Huchon, D. (2012) ALG11 - A new variable DNA marker for sponge phylogeny: Comparison of phylogenetic performances with the $18 \mathrm{~S}$ rDNA and the COI gene. Molecular Phylogenetics and Evolution 63, 702-713.

Bertolino, M., Cerrano, C., Bavestrello, G., Carella, M., Pansini, M. \& Calcinai, B. (2013) Diversity of Porifera in the Mediterranean coralligenous accretions, with description of a new species. ZooKeys 336, 1-37.

Bowerbank, J.S. (1864) A Monograph of the British Spongiadae. Volume 1. Ray Society, London.

Carballo, J.L., Bautista-Guerrero, E. \& Cruz-Barraza, J.A. (2018) Description and molecular phylogeny of Axinella nayaritensis n. sp. (Porifera: Axinellida) from East Pacific and remarks about the polyphyly of the genus Axinella. Zootaxa 4482, 111-124.

Carballo, J.L., Cruz-Barraza, J.A., Vega, C., Nava, H. \& del Carmen Chávez-Fuentes, M. (2019) Sponge diversity in eastern tropical Pacific coral reefs: an interoceanic comparison. Scientific Reports 9, 9409.

Cavalcanti, T., Santos, G.G. \& Pinheiro, U. (2018) Description of three species of Eurypon Gray, 1867 (Raspailiidae: Demospongiae: Porifera) from the Western Atlantic and a name to replace the the secondary homonym Eurypon topsenti. Zootaxa 4388, 89-101.

Chombard, C., Boury-Esnault, N. \& Tillier, S. (1998) Reassessment of homology of morphological characters in tetractinellid sponges based on molecular data. Systematic Biology 47, 351-366.

Claisse, J.T., Blanchette, C.A., Dugan, J.E., Williams, J.P., Freiwald, J.I., Pondella II, D.J., Schooler, N.K., Hubbard, D.M., Davis, K., Zahn, L.A., Williams, C.M. \& Caselle, J.E. (2018) Biogeographic patterns of communities across diverse marine ecosystems in southern California. Marine Ecology 39, e12453.

Desqeyroux-Faundez, R. \& van Soest, R.W.M. (1997) Shallow-water Demosponges of the Galapagos Islands. Revue suisse de Zoologie 104, 379-467. 
Dickinson, M.G. (1945) Sponges of the Gulf of California. In: Reports on the collections obtained by Alan Hancock Pacific Expeditions of Velero III off the coast of Mexico, Central America, South America, and Galapagos Islands in 1932, in 1933, in 1934, in 1935, in 1936, in 1937, in 1939, and 1940. The University of Southern California Press, Los Angeles, pp. 1-55.

Erpenbeck, D., Duran, S., Rützler, K., Paul, V., Hooper, J. \& Wörheide, G. (2007a) Towards a DNA taxonomy of Caribbean demosponges: a gene tree reconstructed from partial mitochondrial CO1 gene sequences supports previous rDNA phylogenies and provides a new perspective on the systematics of Demospongiae. Journal of the Marine Biological Association of the United Kingdom 87, 1563-1570.

Erpenbeck, D., Hall, K., Alvarez, B., Büttner, G., Sacher, K., Schätzle, S., Schuster, A., Vargas, S., Hooper, J. \& Wörheide, G. (2012) The phylogeny of halichondrid demosponges: past and present re-visited with DNA-barcoding data. Organisms Diversity \& Evolution 12, 57-70.

Erpenbeck, D., List-Armitage, S., Alvarez, B., Degnan, B., Wörheide, G. \& Hooper, J. (2007b) The systematics of Raspailiidae (Demospongiae: Poecilosclerida: Microcionina) reanalysed with a ribosomal marker. Journal of the Marine Biological Association of the United Kingdom 87, 1571-1576.

Erpenbeck, D., Voigt, O., Al-Aidaroos, A., Berumen, M., Büttner, G., Catania, D., Guirguis, A., Paulay, G., Schätzle, S. \& Wörheide, G. (2016) Molecular biodiversity of Red Sea demosponges. Marine Pollution Bulletin 105, 507-514.

Folmer, O., Black, M., Wr, H. \& Vrijenhoek, R. (1994) DNA primers for amplification of mitochondrial Cytochrome $\mathrm{C}$ oxidase subunit I from diverse metazoan invertebrates. Molecular marine biology and biotechnology 3, 294-299.

Gazave, E., Carteron, S., Chenuil, A., Richelle-Maurer, E., Boury-Esnault, N. \& Borchiellini, C. (2010) Polyphyly of the genus Axinella and of the family Axinellidae (Porifera: Demospongiae). Molecular Phylogenetics and Evolution 57, 35-47.

Gómez, P., Carballo, J.L., Vázquez, L.E. \& Cruz, J.A. (2002) New records for the sponge fauna (Porifera: Demospongiae) of the Pacific coast of Mexico (eastern Pacific Ocean). Proceedings of the Biological Society of Washington 115, 223-237.

Green, K.D. \& Bakus, G.J. (1994) Taxonomic atlas of the benthic marine fauna of the Western Santa Maria Basin and the Western Santa Barbara Channel. Volume 2: The Porifera. The Santa Barbara Museum of Natural History, $82 \mathrm{pp}$.

Hartman, W.D. (1975) Phylum Porifera. In: R. I. Smith and J. T. Carlton (Eds), Light's Manual: Intertidal Invertebrates of the Central California Coast. Third edition. University of California Press, Berkeley.

Hoang, D., Chernomor, O., von Haeseler, A., Minh, B. \& Vinh, L. (2018) UFBoot2: Improving the ultrafast bootstrap approximation. Molecular Biology and Evolution 35, 518-522. 
Hofknecht, G. (1978) Descriptions and Key to the Intertidal Sponges of the Puerto Peñasco Area in the Gulf of California. Arizona-Nevada Academy of Sciences 13, 51-56.

Holmes, B. \& Blanch, H. (2007) Genus-specific associations of marine sponges with group I crenarchaeotes. Marine Biology 150, 759-772.

Hooper, J.N.A. (1991) Revision of the family Raspailiidae (Porifera: Demospongiae), with description of Australian species. Invertebrate Taxonomy 5, 1179-1418.

Hooper, J.N.A. (2002a) Family Desmoxyidae Hallmann, 1917. In: J. N. A. Hooper and R. W. M. van Soest (Eds), Systema Porifera: A Guide to the Classification of Sponges. Springer, Boston, pp. 755-772.

Hooper, J.N.A. (2002b) Family Microcionidae Carter, 1875. In: J. N. A. Hooper and R. W. M. van Soest (Eds), Systema Porifera: A Guide to the Classification of Sponges. Springer, Boston, pp. 432-468.

Hooper, J.N.A. (2002c) Family Raspailiidae Hentschel, 1923. In: J. N. A. Hooper and R. W. M. van Soest (Eds), Systema Porifera: A Guide to the Classification of Sponges. Springer, Boston, pp. 469-510.

Hooper, J.N.A., Lehnert, H. \& Zea, S. (1999) Revision of Aulospongus Norman and review of Raspailiidae with rhabdostyles (Porifera: Demospongiae). Memoirs of the Queensland Museum 43, 649-708.

Huang, D., Meier, R., Todd, P.A. \& Chou, L.M. (2008) Slow mitochondrial COI sequence evolution at the base of the Metazoan tree and its implications for DNA barcoding. Journal of Molecular Evolution 66, 167-174.

Huchon, D., Szitenberg, A., Shefer, S., Ilan, M. \& Feldstein, T. (2015) Mitochondrial group I and group II introns in the sponge orders Agelasida and Axinellida. BMC Evolutionary Biology 15, 278.

Idan, T., Shefer, S., Feldstein, T., Yahel, R., Huchon, D. \& Ilan, M. (2018) Shedding light on an East-Mediterranean mesophotic sponge ground community and the regional sponge fauna. Mediterranean Marine Science 19, 84-106.

Katoh, K., Rozewicki, J. \& Yamada, K.D. (2017) MAFFT online service: multiple sequence alignment, interactive sequence choice and visualization. Briefings in Bioinformatics 20, 1160-1166.

Kayal, E. \& Lavrov, D.V. (2008) The mitochondrial genome of Hydra oligactis (Cnidaria, Hydrozoa) sheds new light on animal mtDNA evolution and cnidarian phylogeny. Gene 410, 177-186.

Klontz, S.W. (1989) Ecology and systematics of the intertidal sponges of Southeast Farallon Island. Masters. San Francisco State University. 
Lage, A., Carvalho, M.S. \& Menegola, C. (2013) Two new species of Halichondrida (Demospongiae) and the first record of Phycopsis and Ciocalapata for Brazil. Zootaxa 3734, 292-300.

de Laubenfels, M.W. (1927) The red sponges of Monterey Peninsula, California. Annals and Magazine of Natural History 9, 258-266.

de Laubenfels, M.W. (1932) The marine and fresh-water sponges of California. Proceedings of the United States National Museum 81, 1-140.

de Laubenfels, M.W. (1935) Some sponges of Lower California (Mexico). American Museum Novitates $779,1-14$.

Lavrov, D.V., Wang, X. \& Kelly, M. (2008) Reconstructing ordinal relationships in the Demospongiae using mitochondrial genomic data. Molecular Phylogenetics and Evolution 49, 111-124.

Lee, W., Elvin, D. \& Reiswig, H. (2007a) The sponges of California: A guide and key to the marine sponges of California. Monterey Bay Sanctuary Foundation, Monterey, CA.

Lee, W.L., Hartman, W.D. \& Díaz, M.C. (2007b) Porifera. In: J. T. Carlton (Ed), The Light and Smith Manual. University of California Press, pp. 83-117.

Letunic, I. \& Bork, P. (2019) Interactive Tree Of Life (iTOL) v4: recent updates and new developments. Nucleic Acids Research 47, W256-W259.

Lévi, C. (1953) Sur une nouvelle classification des Démosponges. Comptes Rendus de Hebdomadaires des Séances de l'Académie des Sciences, Paris 236.

Lim, S.-C., Wiklund, H., Glover, A.G., Dahlgren, T.G. \& Tan, K.-S. (2017) A new genus and species of abyssal sponge commonly encrusting polymetallic nodules in the ClarionClipperton Zone, East Pacific Ocean. Systematics and Biodiversity 15, 507-519.

López-Legentil, S., Erwin, P.M., Henkel, T.P., Loh, T.L. \& Pawlik, J.R. (2010) Phenotypic plasticity in the Caribbean sponge Callyspongia vaginalis (Porifera: Haplosclerida). Scientia Marina 74, 445-453.

Luke, S.R. (1998) Catalog of the benthic invertebrate collections: Coelenterata. Scripps Institution of Oceanography Reference Series 98-02.

Morozov, G., Sabirov, R.M. \& Anisimova, N. (2018) New data on sponges from Svalbard Archipelago with a description of a new species of Halicnemia. Journal of Natural History 52, 491-507.

Morrow, C., Allcock, L.A. \& Mccormack, G. (2018) A new species of Hymeraphia Bowerbank, 1864 (Axinellida: Raspailiidae) from a deep-water canyon southwest off Ireland. Zootaxa 4466, 61-68. 
Morrow, C. \& Cárdenas, P. (2015) Proposal for a revised classification of the Demospongiae (Porifera). Frontiers in Zoology 12, 1-27.

Morrow, C., Cárdenas, P., Boury-Esnault, N., Picton, B., McCormack, G., van Soest, R., Collins, A., Redmond, N., Maggs, C., Sigwart, J. \& Allcock, L.A. (2019) Integrating morphological and molecular taxonomy with the revised concept of Stelligeridae (Porifera: Demospongiae). Zoological Journal of the Linnean Society 187, 31-81. https://doi.org/10.1093/zoolinnean/zlz017

Morrow, C.C., Picton, B.E., Erpenbeck, D., Boury-Esnault, N., Maggs, C.A. \& Allcock, A.L. (2012) Congruence between nuclear and mitochondrial genes in Demospongiae: A new hypothesis for relationships within the G4 clade (Porifera: Demospongiae). Molecular Phylogenetics and Evolution 62, 174-190.

Morrow, C.C., Redmond, N.E., Picton, B.E., Thacker, R.W., Collins, A.G., Maggs, C.A., Sigwart, J.D. \& Allcock, A.L. (2013) Molecular phylogenies support homoplasy of multiple morphological characters used in the taxonomy of Heteroscleromorpha (Porifera: Demospongiae). Integrative and Comparative Biology 53, 428-446.

Nguyen, L.-T., Schmidt, H., von Haeseler, A. \& Minh, B. (2015) IQ-TREE: A fast and effective stochastic algorithm for estimating maximum likelihood phylogenies. Molecular Biology and Evolution 32, 268-274.

Nichols, S. (2005) An evaluation of support for order-level monophyly and interrelationships within the class Demospongiae using partial data from the large subunit rDNA and cytochrome oxidase subunit I. Molecular Phylogenetics and Evolution 34, 81-96.

Pöppe, J., Sutcliffe, P., Hooper, J.N., Wörheide, G. \& Erpenbeck, D. (2010) CO I barcoding reveals new clades and radiation patterns of Indo-Pacific sponges of the family Irciniidae. PLOS ONE 5, e9950.

Preston, C.M., Wu, K.Y., Molinski, T.F. \& DeLong, E.F. (1996) A psychrophilic crenarchaeon inhabits a marine sponge: Cenarchaeum symbiosum gen. nov., sp. nov. Proceedings of the National Academy of Sciences 93, 6241-6246.

Recinos, R., Pinheiro, U., Willenz, P. \& Hajdu, E. (2020) Three new Raspailiidae Hentschel, 1923 (Axinellida, Demospongiae) from Peru. Zootaxa 4778, 521-545.

Redmond, N.E., Morrow, C.C., Thacker, R.W., Diaz, M.C., Boury-Esnault, N., Cárdenas, P., Hajdu, E., Lôbo-Hajdu, G., Picton, B.E., Pomponi, S.A., Kayal, E. \& Collins, A.G. (2013) Phylogeny and systematics of Demospongiae in light of new small-subunit ribosomal DNA (18S) sequences. Integrative and Comparative Biology 53, 388-415.

Richelle-Maurer, E., Boury-Esnault, N., Itskovich, V.B., Manuel, M., Pomponi, S.A., Van de Vyver, G. \& Borchiellini, C. (2006) Conservation and phylogeny of a novel family of non-Hox genes of the Antp class in Demospongiae (Porifera). Journal of Molecular Evolution 63, 222-230. 
Ristau, D.A. (1977) Shallow-water Demospongiae of North-Central California: Taxonomy and systematics, distribution, and fossilization potential. PhD. University of California, Davis.

Rot, C., Goldfarb, I., Ilan, M. \& Huchon, D. (2006) Putative cross-kingdom horizontal gene transfer in sponge (Porifera) mitochondria. BMC Evolutionary Biology 6, 1-11.

Santos, G.G., Franca, F. \& Pinheiro, U. (2014) Three new species of Eurypon Gray, 1867 from Northeastern Brazil (Poecilosclerida; Demospongiae; Porifera). Zootaxa 3895, 273-284.

Schmidt, O. (1862) Die Spongien des adriatischen Meeres. Wilhelm Engelmann, Leipzig, 88 pp.

Schneider, C., Rasband, W. \& Eliceiri, K. (2012) NIH Image to ImageJ: 25 years of image analysis. Natue Methods 9, 671-675.

Schuster, A., Strehlow, B.W., Eckford-Soper, L., McAllen, R. \& Canfield, D.E. (2021) Effects of seasonal anoxia on the microbial community structure in Demosponges in a marine lake in Lough Hyne, Ireland. mSphere 6, e00991-20. https://doi.org/10.1128/mSphere.0099120

Sim, C.J. \& Bakus, G.J. (1986) Marine sponges of Santa Catalina Island, California. Occasional Papers of the Allan Hancock Foundation 5, 1-23.

Simon, U.K. \& Weiss, M. (2008) Intragenomic variation of fungal ribosomal genes is higher than previously thought. Molecular Biology and Evolution 25, 2251-2254.

Smith, V.E. (1968) Comparative cytology and biochemistry of two marine sponges. PhD. University of California, San Diego.

van Soest, R., Carballo, J.L. \& Hooper, J. (2012) Polyaxone monaxonids: revision of raspailiid sponges with polyactine megascleres (Cyamon and Trikentrion). ZooKeys 239, 1-70. https://doi.org/10.3897/zookeys.239.3734

van Soest, R.W.M., Boury-Esnault, N., Hooper, J.N.A., Rützler, K., de Voogd, N.J., Alvarez, B., Hajdu, E., Pisera, A.B., Manconi, R., Schönberg, C., Klautau, M., Kelly, M., Vacelet, J., Dohrmann, M., Díaz, M.-C., Cárdenas, P., Carballo, J.L., Ríos, P., Downey, R. \& Morrow, C.C. (2021) World Porifera Database. Available from: http://www.marinespecies.org/porifera/porifera.php?p=taxdetails\&id=845472 (October 1 , 2021)

van Soest, R.W.M., Diaz, M.C. \& Pomponi, S.A. (1990) Phylogenetic classification of the Halichondrids (Porifera Demospongiae). Beaufortia 40, 15-62.

Thacker, R., Hill, A., Hill, M., Redmond, N., Collins, A., Morrow, C., Spicer, L., Carmack, C., Zappe, M., Pohlmann, D., Hall, C., Diaz, M. \& Bangalore, P. (2013) Nearly complete 28S rRNA gene sequences confirm new hypotheses of sponge evolution. Integrative and Comparative Biology 53, 373-387. 
Trifinopoulos, J., Nguyen, L.-T., von Haeseler, A. \& Minh, B. (2016) W-IQ-TREE: a fast online phylogenetic tool for maximum likelihood analysis. Nucleic Acids Research 44, W232W235.

Turner, T.L. (2020) The order Tethyida (Porifera) in California: taxonomy, systematics, and the first member of the family Hemiasterellidae in the Eastern Pacific. Bioarxve doi: 10.1101/2020.04.05.026518.

Turner, T.L. (2021) Four new Scopalina from Southern California: the first Scopalinida (Porifera: Demospongiae) from the temperate Eastern Pacific. Zootaxa 4970, 353-371.

Turon, M., Caliz, J., Garate, L., Casamayor, E.O. \& Uriz, M.J. (2018) Showcasing the role of seawater in bacteria recruitment and microbiome stability in sponges. Scientific Reports 8,15201 .

Vargas, S., Schuster, A., Sacher, K., Büttner, G., Schätzle, S., Läuchli, B., Hall, K., Hooper, J.N.A., Erpenbeck, D. \& Wörheide, G. (2012) Barcoding sponges: An overview based on comprehensive sampling. PLoS ONE 7, e39345. 